\title{
DEVOCIONES DE INMIGRANTES. INDÍGENAS ANDINOS Y PLURIETNICIDAD URBANA EN LA CONFORMACIÓN DE COFRADÍAS COLONIALES (SANTIAGO DE CHILE, SIGLO XVII) ${ }^{* *}$
}

\begin{abstract}
RESUMEN
En los orígenes de Chile colonial nos encontramos con numerosos indígenas andinos que sirvieron a los españoles, se asentaron y se integraron en los espacios laborales y sociales de este "nuevo mundo" periférico; formaron redes y parentescos locales, tuvieron descendencia, varios se transformaron en artesanos y algunos dictaron testamentos o dejaron huellas en documentos eclesiásticos y notariales que nos permiten observar su participación en las cofradías de la capital chilena. Estas corporaciones, por su parte, si bien remiten a una finalidad eminentemente religiosa, también actúan como un canal privilegiado para la inserción y movilidad de población diversa. Bajo esta perspectiva, nuestro artículo analiza las principales cofradías en las cuales participaron estos inmigrantes, vinculando prácticas religiosas, redes sociales y espacios laborales. Las cofradías estudiadas se revelan, entonces, como instancias representativas de la diversidad de orígenes geográficos y étnicos de sus integrantes, así como de la pluralidad de referentes identitarios que circulaban e interactuaban en un escenario urbano colonial como Santiago de Chile.
\end{abstract}

Palabras clave: cofradías, indígenas, Chile colonial, inmigrantes, Perú, diversidad étnica.

\begin{abstract}
In the origins of colonial Chile it is possible to find numerous Andean Indians who worked for Spaniards, settled and were integrated in labor and social spaces of this peripheral "new world". They established local nets and relationships, and had descendants. Many became craftmen and some left wills or traces on ecclesiastic and notarial documents that allow us to observe their participation in brotherhoods created in Chile's capital. These corporations had a religious aim, but worked as
\end{abstract}

* Docteur en Histoire et Civilisations, École des Hautes Études en Sciences Sociales, París. Profesor, investigador y coordinador del Laboratorio de Historia Colonial del Instituto de Historia, Pontificia Universidad Católica de Chile. Correo electrónico: jvalenzm@uc.cl

** Este trabajo forma parte del proyecto de investigación "Inmigrantes indígenas. Indios 'cuzcos' y huarpes en Chile colonial (siglos XVI-XVII)", financiado por FONDECYT (N ${ }^{\circ} 1070451,2007$ 2010). Agradecemos la colaboración de Hugo Contreras y Patricia Palma, así como la lectura, comentarios y sugerencias de Emma de Ramón y Juan Carlos Estenssoro. 
privileged channels for the insertion and mobility of diverse people. Under this premise, this article analyzes the main brotherhoods in which these immigrants participated, linking religious practices with their social nets and working spaces. The brotherhoods studied reveal themselves as instances that represent the diversity of geographic and ethnic origins of its members, as well as the multiple points of reference for their identities, that circulated and interacted in a colonial urban space such as Santiago of Chile.

Key words: Brotherhoods, Colonial Chile, Immigrants, Peru, Ethnic Diversity.

Fecha de recepción: septiembre de 2009

Fecha de aceptación: marzo de 2010

Siguiendo la tradición medieval que subyacía a las estructuras y a las formas de las prácticas religiosas desplegadas por los españoles en América, la experiencia devocional reproducirá aquí los ribetes corporativos propios del paradigma europeo dominante en la época de la conquista; paradigma que luego será reforzado por la cultura contrarreformista que se desplegará desde fines del siglo XVI ${ }^{1}$.

Las cofradías serán, pues, aquellas instancias privilegiadas para canalizar la devoción de los laicos en el escenario festivo, para intentar un seguimiento tridentino de las prácticas católicas -vinculando la piedad colectiva con las instituciones eclesiásticas- y para brindar un apoyo espiritual y material a la hora de enfrentar los ritos de la muerte. En esta misma línea, también servirán para cultivar la memoria de los cofrades difuntos -a través de misas anuales- o para asistir a los miembros activos ante algún problema económico circunstancial ${ }^{2}$. Para esto último se contaba con los

1 En España, a mediados del siglo XVII se contaban alrededor de veinte mil cofradías. Entre ellas se diferenciaban las integradas por mercaderes y artesanos, las compuestas por profesionales liberales (médicos, abogados, etc.) y aquellas que tenían una base regional, de carácter rural. Al igual que los gremios, ellas cumplían un fin caritativo hacia sus miembros. Su disposición, por otra parte, respondía a una jerarquía que dependía de la categoría social de sus integrantes y de los poderes de la advocación patronal a la cual se orientaba su culto: Marcellin Defourneaux, La vida cotidiana en la España del Siglo de Oro, Barcelona, Argos Vergara, 1983, 111-122. Una aproximación a las cofradías americanas en el contexto ideológico del catolicismo europeo de la época, en Joaquín Rodríguez Mateos, "Las cofradías de Perú en la modernidad y el espíritu de la Contrarreforma", en Anuario de estudios americanos LII:2, Sevilla, 1995, 15-43.

2 La bibliografía sobre cofradías y hermandades es abundante. Un estudio pionero y clásico sobre las cofradías europeas es el de Gabriel Le Bras, "Les confréries chrétiennes. Problèmes et propositions" [1940], en G. Le Bras (comp.), Études de sociologie religieuse, París, Presses Universitaires de France, 1955-1956, II, 423-462. Para una mirada general al mundo peninsular, véase Defourneaux, op. cit., y la serie de trabajos que bajo el título "Asociaciones: hermandades, cofradías y mayordomías" se publican en Carlos Álvarez Santaló et al. (coords.), La religiosidad popular, Barcelona, Anthropos, Fundación Machado, 1989, III, 447-650. Una revisión de las características jurídicas, sociales y religiosas, en el contexto barroco de la España del siglo XVII, en Inmaculada Arias de Saavedra y Miguel Luis López-Guadalupe, "Las cofradías y su dimensión social en la España del Antiguo Régimen", en Cuadernos de historia moderna 25, Madrid, 2000, 189-232; y en Tomás Mantecón Movellán, "Historia de las ideas e historia social. Problemas y métodos a partir del estudio de las cofradías contrarreformistas", en Santiago Castillo (coord.), La historia social en España. Actualidad y perspectivas, Madrid, Siglo XXI, 1990, 305-310. Una aproximación antropológica clásica es la de 
pagos regulares de los integrantes, las limosnas recolectadas entre los habitantes locales y -dependiendo de su grado de importancia- con las rentas provenientes de préstamos o del arriendo de bienes inmuebles que formaban parte de su capital institucional, dejados como legado por cofrades fallecidos ${ }^{3}$.

George M. Foster, "Cofradía and Compadrazgo in Spain and Spanish America", en Southwestern Journal of Anthropology IX:1, Albuquerque, 1953, 1-28. Para América, véase Pilar Martínez LópezCano et al. (eds.), Cofradías, capellanías y obras pías en la América colonial, México, Universidad Nacional Autónoma de México, 1998. Respecto de las cofradías como espacios de integración social y étnica, véase la compilación de trabajos publicada por Albert Meyers y Diane Elizabeth Hopkins (eds.), Manipulating the Saints. Religious Brotherhoods and Social Integration in Postconquest Latin America, Hamburg, Wayasbah, 1988. Para el Perú: Rafael Varón, "Cofradías de indios y poder local en el Perú colonial: Huaraz, siglo XVII", en Allpanchis XVII:20, Cuzco, 1983, 127-146; Beatriz Garland, "Las cofradías en Lima durante la Colonia. Una primera aproximación", en Gabriela Ramos (comp.), La venida del Reino. Religión, evangelización y cultura en América. Siglos XVI-XX, Cuzco, Centro Bartolomé de Las Casas, 1994, 199-228; Jesús Paniagua Pérez, "Cofradías limeñas: San Eloy y la Misericordia (1597-1733)", en Anuario de estudios americanos LII:1, Sevilla, 1995, 13-35; Diego Lévano Medina, "Organización y funcionalidad de las cofradías urbanas. Lima, siglo XVII", en Revista del Archivo General de la Nación 24, Lima, 2002, 77-118; Ciro Corilla, "Cofradías en la ciudad de Lima, siglos XVI y XVII: racismo y conflictos étnicos", en Ana Carrillo (ed.), Etnicidad y discriminación racial en la historia del Perú, Lima, Pontificia Universidad Católica del Perú, Instituto Riva Agüero, 2002, 11-34; Walter Vega Jácome, "Cofradías limeñas", en Laura Gutiérrez Arbulú (ed.), Lima en el siglo XVI, Lima, Pontificia Universidad Católica del Perú, 2005, 703-752. Para México: Richard E. Greenleaf, "The Inquisition Brotherhood: Cofradía de San Pedro Martir of Colonial Mexico", en The Americas LX:2, Maryland, 1983, 171-207; Alicia Bazarte Martínez, Las cofradías de españoles en la ciudad de México (1526-1860), México, Universidad Autónoma Metropolitana, 1989; María del Carmen Pareja Ortiz, "Religiosidad popular y caridad asistencial en cofradías de Nueva España en el siglo XVIII", en Hispania sacra XLIII:88, Madrid, 1991, 625-646; Dagmar Bechtloff, Las cofradías en Michoacán durante la época de la colonia. La religión y su relación política y económica en una sociedad intercultural, Zinacantepec, El Colegio de Michoacán, El Colegio Mexiquense, 1996; Larissa Taylor et al., Nahua Confraternities in Early Colonial Mexico: The $1552 \mathrm{Na}$ huatl Ordinances of Fray Alonso de Molina, OFM, Berkeley, Academy of American Franciscan History, 2002. Para otras regiones: Gary W. Graff, Cofradias in the New Kingdom of Granada: Lay Fraternities in a Spanish American Frontier Society, 1600-1755, tesis doctoral inédita, University of Wisconsin, Michigan, 1973; Carmen Ferreira Esparza, "Nuestra Señora de las Angustias del pueblo de indios de Labateca: la doble cara de la cofradía colonial", en Anuario VI. Historia regional de las fronteras, Santander, Universidad Industrial de Santander, 2001, 455-483; Ana María Martínez de Sánchez, Cofradías y obras pías en Córdoba del Tucumán, Córdoba, Advocatus, 2006; Luis di Nucci, "Las cofradías santafesinas como experiencias de convivencia y dominación", en Actas de las III Jornadas "Experiencias de la diversidad", Rosario, Universidad Nacional de Rosario, 2008 (formato CD); María Candela de Luca, "Las cofradías de indios en el territorio de Charcas (siglo XVIII): balance historiográfico y nuevas propuestas de análisis", ponencia inédita presentada en II Jornadas nacionales de historia social, Córdoba, 13-15 de mayo de 2009.

3 Alicia Bazarte, "Las limosnas de las cofradías: su administración y destino", en Martínez LópezCano et al. (eds.), op. cit., 65-74; Asunción Lavrín, "Cofradías novohispanas: economías material y espiritual", en ibid., 49-64; de esta misma autora, "Mundos en contraste: cofradías rurales y urbanas en México a fines del siglo XVIII", en Arnold Bauer (ed.), La Iglesia en la economía de América Latina, siglos XVI al XIX, México, Instituto Nacional de Antropología e Historia, 1986, 235-275; Clara García Ayluardo, "Las cofradías como fuentes para la historia económica del México colonial", en Boletín de fuentes para la historia económica de México 3, México, 1991, 17-22; Patricia Fogelman, "Una cofradía mariana urbana y otra rural en Buenos Aires a fines del período colonial", en Andes 11, Salta, 2000, 179207. Sobre los bienes y la administración del patrimonio cofradial, en relación con las dinámicas de poder internas, Olinda Celestino y Albert Meyers presentan el caso de la cofradía de la Virgen del Carmen, fundada en la ciudad andina de Jauja. Esta incorporó a diversas comunidades indígenas cercanas, aunque mantuvo los espacios de control en manos de curacas que alimentaban su legitimidad, justamente, con este tipo de manejo económico e integración colonial: "La dinámica socioeconómica del patrimonio cofradial en el Perú colonial: Jauja en el siglo XVII", en Revista española de antropología 
Junto con ello, las cofradías otorgaban la posibilidad de generar un espacio de sociabilidad para personas vinculadas por lazos sociales, laborales o étnicos. Habrá algunas de gran prestigio -integradas por lo más granado de la élite local-, otras que refrendaban las redes gremiales de determinadas especialidades artesanales y otras que, en el contexto de la realidad americana, vinculaban a personas clasificadas por el sistema colonial en determinadas categorías "étnicas" -"morenos", "indios", "castas"-4. También habrá, por cierto, como veremos en los casos estudiados más adelante -y como también sucedía en otras ciudades de la épocacofradías mixtas y plurales, donde convivían y practicaban su religiosidad integrantes de diferente origen y condición, respondiendo así a las complejas realidades pluriétnicas que se articulaban en las urbes americanas y, al mismo tiempo, a las dimensiones demográficamente más reducidas de ciudades como Santiago ${ }^{5}$.

americana XI, Madrid, 1981, 183-206 (es necesario consignar que, pese al título, este estudio se refiere al siglo XVIII). En este mismo plano, véase Dorothy Tanck de Estrada, "Cofradías en los pueblos de indios en el México colonial”, en $3^{\text {er }}$ Congreso virtual de antropología y arqueología, 2002: www.naya.org.ar/congreso2002/ponencias/dorothy_tanck_de_estrada.htm Con respecto a los beneficios y obligaciones espirituales y materiales, véase también Philippe Ariès, El hombre ante la muerte, Madrid, Taurus, 1983 [1977], 157-160; María Eugenia Horvitz, "Capellanías de misas: memorial de vida, muerte y trascendencia", en María Eugenia Horvitz (dir.), Memoria del nombre y salvación eterna. Los notables y las capellanías de misas en Chile, 1557-1930, Santiago, Universidad de Chile, Departamento de Ciencias Históricas, 2006, 33-133.

4 En Lima, por ejemplo, hacia 1613 había un total de 57 cofradías, 25 de las cuales eran de españoles, 13 de indios y 19 de negros: Diego Lévano Medina, "El mundo imaginado: la Cofradía de Nuestra Señora de Copacabana y la religiosidad andina manifestada”, en Fernando Armas Asin (ed.), Angeli Novi. Prácticas evangelizadoras, representaciones artísticas y construcciones del catolicismo en América (siglos XVII-XX), Lima, Pontificia Universidad Católica del Perú, 2004, 115; cf. Olinda Celestino y Albert Meyers, Las cofradías en el Perú: región central, Frankfurt, Verlag Klaus Dieter Vervuert, 1981, 121; cf., también, Meyers y Hopkins (eds.), op. cit. Sobre cofradías de "negros", véase Nicole von Germeten, Black Blood Brothers: Confraternities and Social Mobility for Afro-Mexicans, Gainesville, University Press of Florida, 2006; Norberto Pablo Cirio, “¿Rezan o bailan? Disputas en torno a la devoción a san Baltazar por los negros en el Buenos Aires colonial”, en Víctor Rondón (ed.), Mujeres, negros y niños en la música y sociedad colonial iberoamericana, Santa Cruz de la Sierra, Asociación Pro Arte y Cultura, 2002, 88-100.

Véase, por ejemplo, el trabajo de Judith Mansilla sobre la diversidad indígena en la composición de la cofradía de Copacabana de Lima: "Exteriorizando la religiosidad: los 'indios ricos' en su lucha por el manejo de la capilla de la Virgen de Copacabana", ponencia inédita presentada al VII Congreso internacional de etnohistoria, Lima, 4-7 de agosto de 2008; Walter Vega, en "Cofradías limeñas", op. cit., presenta el caso de la cofradía franciscana de Nuestra Señora de los Reyes, que llegó a albergar hasta ocho castas en su interior: 744-745. En general, véanse también los trabajos de Iris Gareis, "Religión popular y etnicidad: la población indígena de Lima colonial", en Allpanchis 40, Cuzco, 1992, 117 143; Lyn Lowry, "Religión y control social en la colonia. El caso de los indios urbanos de Lima, 15701620", en Allpanchis 32, Cuzco, 1988, 11-41; Ana María Presta, "Devoción cristiana, uniones consagradas y elecciones materiales en la construcción de identidades indígenas urbanas. Charcas, 15501650", en Revista Andina 41, Cuzco, 2005, 109-130; Dagmar Bechtloff, "La formación de una sociedad intercultural: las cofradías en el Michoacán colonial”, en Historia mexicana XLIII:2, México, 1993, 251263. Sobre la diversidad étnica en otras ciudades coloniales iberoamericanas, véanse los trabajos de Carmen Bernand y Serge Gruzinski, Histoire du Nouveau Monde, II: Les métissages (1550-1640), París, Fayard, 1993, 250-285; Louisa Hoberman y Susan Socolow (comps.), Ciudades y sociedad en Latinoamérica colonial, Buenos Aires, Fondo de Cultura Económica, 1992 [1986]; Woodrow Borah y Serborne F. Cook, "The Urban Center as a Focus of Migration in the Colonial Period: New Spain", en Richard P. Schaedel et al. (eds.), Urbanization in the Americas from its Beginnings to the Present, Chicago, Walter De Gruyter Inc., 1978, 383-398; Serge Gruzinski, "Genèse des plèbes urbaines coloniales: Mexico aux $\mathrm{XVI}^{\mathrm{e}}$ et XVII ${ }^{\mathrm{e}}$ siècles", Caravelle 84, Toulouse, 2005, 11-35. 
De esta forma, el esquema de cofradías implantado en América tuvo que comprender, además de los criterios profesionales y sociales característicos del mundo europeo, el criterio étnico ${ }^{6}$. La institucionalidad religiosa se impregnaba, así, del mestizaje biológico y cultural que estructuraba la sociedad colonial, y tanto los neófitos indígenas como los africanos y las "castas" fueron incorporados plenamente al sistema de signos y de prácticas desplegado por la Iglesia en el conjunto de la sociedad. Esta institución, en efecto, se prestó fácilmente para canalizar esa integración, pues el organigrama de cofradías era lo suficientemente flexible como para diseñar criterios de selección que incluyesen a los nuevos actores americanos. Y será a través de estas organizaciones que se orientará institucionalmente el adoctrinamiento y la preparación para la actuación devocional de aquellos grupos en el calendario litúrgico ${ }^{7}$.

La cofradía era, entonces, una instancia que aportaba un marco identitario a sus integrantes; una identidad corporativa bajo la cual los no hispanocriollos podían presentarse ante el sistema colonial, definir su nivel de compromiso con él y, por lo tanto, reivindicar cierto grado de integración simbólica y de prestigio; elementos que podían ostentar frente a la Iglesia, al Estado y a los otros grupos de la socie$\mathrm{dad}^{8}$. Una instancia útil sobre todo en el período temprano de la posconquista, cuando las cofradías "de indios", particularmente en los espacios rurales, pudieron erigirse como nuevas instancias de integración comunitaria, ante el quiebre de los mecanismos tradicionales prehispánicos que delineaban, por ejemplo, las redes de parentesco y de solidaridad en los ayllu andinos ${ }^{9}$. Una instancia, en fin, que brin-

6 Es necesario matizar esta afirmación pues en Sevilla, por la gran cantidad de población esclava existente en la ciudad, sí existían cofradías compuestas exclusivamente por negros. Olinda Celestino, "El trasplante de las cofradías españolas y su diferenciación étnico-social en Lima", en Boletín de historia y geografía 9, Santiago, 1992, 104-126; Carmen Mena García, "Las hermandades de Sevilla y su proyección americana: estudio comparativo de la Cofradía de Nuestra Señora de los Ángeles o 'de los negritos' de Sevilla y de la Cofradía de Santa Ana de Panamá”, en Pilar García Jordán (coord.), Estrategias de poder en América Latina, VII Encuentro-Debate “América Latina ayer y hoy”, Barcelona, Universidad de Barcelona, 2000, 129-150.

7 Sobre las formas religiosas y paradigmas festivos de la época, León Carlos Álvarez Santaló, "El espectáculo religioso barroco", en Manuscrits. Revista d'Historia Moderna 13, Barcelona, 1995, 157-183; José Luis Bouza Álvarez, Religiosidad contrarreformista y cultura simbólica del Barroco, Madrid, CSIC, 1990; William Christian, Religiosidad local en la España de Felipe II, Madrid, Nerea, 1991; Antonio Domínguez Ortiz, "Iglesia institucional y religiosidad popular en la España barroca", en Pierre Córdoba y Jean-Pierre Étienvre (eds.), La fiesta, la ceremonia, el rito, Madrid-Granada, Casa de Velázquez, Universidad de Granada, 1990, 9-20; José Antonio Maravall, La cultura del Barroco. Análisis de una estructura histórica, Barcelona, Ariel, 1980; Antoinette Molinié (ed.), Le Corps de Dieu en fêtes, París, Cerf, 1996; Rafael Ramos Sosa, "La fiesta barroca en ciudad de México y Lima", Historia 30, Santiago, 1997, 263-286.

8 Juan Carlos Estenssoro, Del paganismo a la santidad. La incorporación de los indios del Perú al catolicismo (1532-1750), Lima, IFEA, Instituto Riva-Agüero, 2003, 443-444.

9 Celestino y Meyers, Las cofradías..., op. cit., 43 y 125-126; de los mismos autores, "La dinámica...", op. cit., 184; Varón, op. cit., 135-136. Carlos Zanolli, por su parte, presenta el caso de las cofradías fundadas durante el siglo XVII en el pueblo de San Antonio de Humahuaca, al sur de Charcas. Este último fue establecido en función de los intereses del encomendero local, mientras que sus cofradías se orientaron a agrupar a la nueva "comunidad" indígena que se formó con la concentración de los indios de las cercanías, luego de ser asignados a dicha encomienda: Tierra, encomienda e identidad: Omaguaca (1540-1638), Buenos Aires, Sociedad Argentina de Antropología, 2005, 185-191. Para la misma región, aunque en la segunda mitad del siglo XVIII, Enrique Normando Cruz analiza el mantenimiento de 
daba "un sentido de pertenencia" 10 , tanto más efectivo en la medida en que el despliegue de las nuevas formas coloniales de organización laboral y administrativa -las reducciones del virrey Francisco de Toledo en el Perú, por ejemplo- conllevó el desplazamiento y reubicación de numerosas poblaciones indígenas y, para el mundo urbano, la convivencia cotidiana entre personas de diferentes orígenes, colores y estatus ${ }^{11}$.

En estos contextos "caóticos" de la Colonia temprana, entonces, las cofradías se alzaban como una suerte de "familias", unidas por un parentesco espiritual, que otorgaban cohesión social y seguridad económica, por ejemplo, a los indígenas del Cuzco, debilitados por las epidemias y la depresión económica. Las corporaciones surgidas en la capital inca fueron, así, más allá de las delimitaciones del barrio parroquial o de determinadas lealtades étnicas, congregando en torno a una advocación particular a poblaciones étnica y socialmente diversas ${ }^{12}$.

patrones de relaciones tradicionales rurales y de identificación étnica entre los indígenas que integraron una cofradía que funcionó en la ciudad de Jujuy: "Una cofradía urbana de indios a fines de la colonia: San Pedro de Naturales (Jujuy-Río de la Plata)", en Revista Andina 44, Cuzco, 2007, 227-248. Para un análisis general de las transformaciones sociales, materiales y étnicas que sufren las poblaciones andinas, véase el trabajo clásico de Karen Spalding, De indio a campesino. Cambios en la estructura social del Perú colonial, Lima, Instituto de Estudios Peruanos, 1974.

10 Paul Charney, "A Sense of Belonging: Colonial Indian Cofradías and Ethnicity in the Valley of Lima, Peru", en The Americas LIV:3, Maryland, 1998, 379-407.

11 Cf. Noble David Cook, "Les indiens immigrés à Lima au début du XVII" siècle", en Cahiers des Amériques Latines 13/14, París, 1976, 33-50; Claude Mazet, "Population et societé a Lima aux XVI et XVII ${ }^{\mathrm{e}}$ siècles: la paroisse San Sebastian (1562-1689)”, en Cahiers des Ameriques Latines 13/14, París, 1976, 51-100; Fred Bronner, "The Population of Lima, 1593-1637: In Quest of a Statistical Bench Mark", en Ibero Amerikanische Archiv V:2, Berlín, 1979, 107-120; Hugo Pereyra Placencia, "Indios y mestizos en la Lima de los siglos XVI y XVII", en Cielo abierto XI:32, Lima, 1985, 49-57; Paul Charney, "El indio urbano. Un análisis económico y social de la población india de Lima en 1613", en Histórica XII:1, Lima, 1988, 5-33; del mismo autor, "Negotiating Roots: Indian Migrants in the Lima Valley during the Colonial Period", en John E. Kicza (ed.), The Indian in Latin American History. Resistance, Resilience, and Acculturation, Wilmington (DE), Scholarly Resources Inc., 2000, 139-156; también, Indian Society in the Valley of Lima, Peru, 1532-1824, Lanham (Md), University Press of America, 2001; Lyn Lowry, Forging an Indian Nation: Urban Indians Under Spanish Colonial Control (Lima, Peru, 1535-1765), Tesis Doctoral (inédita), University of California, Berkeley, 1991; Teresa Vergara, "Migración y trabajo femenino a principios del siglo XVII: el caso de las indias de Lima", en Histórica XXI:1, Lima, 1997, 135-157; Jesús Cosamalón Aguilar, Indios detrás de la muralla. Matrimonios indígenas y convivencia interracial en Santa Ana (Lima, 1795-1820), Lima, Pontificia Universidad Católica del Perú, 1999; Nicolás Sánchez Albornoz, "Migración urbana y trabajo. Los indios de Arequipa, 1571-1645", en Sergio Bagú et al. (eds.), De historia e historiadores. Homenaje a José Luis Romero, México, Siglo XXI, 1982, 259-281; Ann M. Wightman, Indigenous Migration and Social Change. The Forasteros of Cuzco, 1570-1720, Durham-London, Duke University Press, 1990; Ana María Lorandi, "Ni tradición ni modernidad. El mestizaje en contextos sociales desestructurados", Relaciones de la Sociedad Argentina de Antropología XVIII, Buenos Aires, 1990-1992, 93-120; Jacques Poloni Simard, "Formación, desarrollo y configuración socio-étnica de una ciudad colonial: Cuenca, siglos XVI-XVIII", en Anuario de estudios americanos LIV:2, Sevilla, 1997, 413-445; del mismo autor, La mosä̈que indienne. Mobilité, stratification sociale et métissage dans le corregimiento de Cuenca (Équateur) du XVIe au XVIIIe siècle, París, École des Hautes Études en Sciences Sociales, 2000 (ed. en castellano: Quito, AbyaYala, IFEA, 2006); John K. Chance, "The Urban Indian in Colonial Oaxaca", en American Ethnologist III:4, Arlington (VA), 1976, 603-632; Marta Zambrano Escovar, Trabajadores, villanos y amantes: encuentros entre indígenas y españoles en la ciudad letrada. Santa Fe de Bogotá (1550-1650), Bogotá, Instituto Colombiano de Antropología e Historia, 2008.

12 Carolyn Dean, "Familiarizando el catolicismo en el Cuzco colonial”, en Jean-Jacques Decoster (ed.), Incas e indios cristianos. Elites indígenas e identidades cristianas en los Andes coloniales, Lima, Centro Bartolomé de Las Casas, IFEA, 2002, 175-176. 
En otras palabras, ser miembro de una cofradía, sobre todo para aquellas personas de grupos discriminados, subvalorados y desarraigados -en el caso de los individuos o grupos desplazados geográficamente- no solo implicaba una mayor cercanía con la posibilidad de salvación post mortem, sino también una determinada forma de integración, de regeneración comunitaria, de movilidad social y de reconocimiento, pensando en aquellos que estaban en proceso de asentamiento y ascenso. Para los que ya lo habían logrado, podía ayudar a refrendar y enriquecer la nueva condición, actuando como una fuente adicional de posicionamiento sociorreligioso. Esto último también lo veremos en los casos que estudiaremos más adelante, toda vez que las cofradías donde se insertarán los inmigrante andinos de Santiago pueden ser vistas no solo como instancias de producción de identidad corporativa, sino también, en sentido inverso, como espacios que más bien la cristalizan, que contribuyen a una integración ya manifiesta y que posibilitan una socialización de individuos que ya muestran vinculaciones previas -especialmente en relación con sus actividades artesanales-.

De ahí la importancia que tenía para sus miembros -fuesen grandes encomenderos, modestos albañiles, indios urbanos o negros libertos- no solo el pago regular de la cuota que les aseguraba un entierro digno y con las necesarias solemnidades, sino también acceder a los cargos internos y participar activamente en el calendario litúrgico de la Iglesia. Dentro de este, se daba una especial atención a la fiesta de la advocación tutelar de la corporación -cuya imagen generalmente era venerada en la capilla "propia" que se ubicaba al interior del respectivo templo-, saliendo al espacio público con la ostentación de sus mejores ropas y atuendos, y conforme al orden jerárquico de cada uno de sus miembros.

Porque, sin duda, la jerarquía visual -como la social- era una regla fundamental a la hora de descifrar los matices de poder que circulaban entre sus integrantes. Poderes que se cristalizaban en los cargos de mayordomo -que administraba los ingresos y gastos, organizaba las actividades y servía de nexo con la comunidad religiosa que la albergaba-, de procurador y de veinticuatro, el grupo de mayor influencia, con voto activo y pasivo en las elecciones y en las decisiones de la hermandad. Estructura administrativa que, por cierto, respondía a las formas tradicionales de las cofradías europeas; pero que también, observada a nivel local, implicaba la reivindicación de prestigios simbólicos y la asignación de espacios de poder entre pares sociales y étnicos; espacios que, a su vez, permitían acrecentar su estatus y prestigio ${ }^{13}$. De ahí la importancia del análisis que podamos hacer respecto de las elecciones internas y de los posicionamientos relativos que puedan adoptar, a través del tiempo, los inmigrantes andinos que integraban las cofradías santiaguinas.

13 Celestino y Meyers, "La dinámica...", op. cit.; John K. Chance y William B. Taylor, "Cofradías and Cargos: An Historical Perspective on the Mesoamerican Civil-Religious Hierarchy", en American Ethnologist XII:1, Arlington (VA), 1985, 1-26. Una dinámica similar se puede observar en las cofradías de negros y mulatos en el Brasil colonial: A. J. R. Russell-Wood, "Black and Mulatto Brotherhoods in Colonial Brasil: A Study in Collective Behavior", en The Hispanic American Historical Review LIV:4, Durham, 1974, 567-602. 
Dicha jerarquía no solo definirá la organización interna de sus integrantes, sino que también alimentará el organigrama del conjunto de las cofradías de una localidad. Esto porque cada una de ellas pugnaba por posicionarse en el escalafón que definía la ubicación en las procesiones -y, por lo tanto, en el prestigio y la consideración social de cada corporación- de acuerdo a la antigüedad en su fecha de fundación. Situación que muchas veces daba origen a litigios y competencias ventiladas ante la autoridad eclesiástica, y donde se verán comprometidas, también, las órdenes religiosas bajo cuyo alero estaban constituidas ${ }^{14}$.

Desde la perspectiva de la Iglesia y del Estado, por su parte, estas corporaciones se mostraban funcionales al paradigma corporativo bajo el cual se pretendía organizar a la sociedad colonial. La Iglesia abarcaba a todos los grupos sociales, canalizando la religiosidad colectiva en forma diferenciada, mientras que el orden y las jerarquías se mantenían en su objetividad cotidiana y en la subjetividad de las formas y estructuras festivas, dando al mismo tiempo la sensación de unión social y espiritual ${ }^{15}$.

\section{EL CONTEXTO: RELIGIOSIDAD Y COFRADÍAS EN EL SANTIAGO BARROCO}

Las cofradías, en efecto, permitían, al menos teóricamente, vigilar a los fieles y aplicar las disposiciones eclesiásticas dispuestas por el Concilio de Trento, a partir de su implementación americana con el III Concilio limense (1582-1583) ${ }^{16}$. El mundo contrarreformista, además, daba una alta validación a la experiencia pública de la devoción volcada a la calle a través de las procesiones, que reforzaban en la práctica, por medio de la experiencia visual y corporal, los avances del adoctrinamiento y de la incorporación a los parámetros conductuales que el sistema colonial definía para los distintos segmentos de la sociedad ${ }^{17}$; aunque, sabemos, se trataba de una incorporación siempre "negociada" en términos culturales, pues los no hispanos estaban lejos de ser actores pasivos de un proceso cuyos resultados híbridos, si bien pudieron acomodarse al paradigma barroco vigente, estuvieron bastan-

\footnotetext{
14 Véase, por ejemplo, para el arzobispado de Lima, el conflicto que describe Rubén Vargas Ugarte, Historia de la Iglesia en el Perú, Burgos, Imprenta de Aldecoa, 1959-1962, II, 494-497.

15 Cf. José Jaime García Bernal, "Vínculo social y vínculo espiritual: la fiesta pública en la España Moderna", en Lucien Clare, Jean Paul Duviols y Annie Molinié (dirs.), Fêtes et divertissements, Presses de l'Université de Paris-Sorbonne, Ibérica, nouvelle série, 8, 1997, 15-40. Véase también nuestro trabajo "Del orden moral al orden político. Contextos y estrategias del discurso eclesiástico en Santiago de Chile", en Bernard Lavallé (ed.), Máscaras, tretas y rodeos del discurso colonial en los Andes, Lima, IFEA, Instituto Riva-Agüero, 2005, 121-137.

16 Tercera sesión (23 septiembre 1583), cap. 44: "De las cofradías", en Francesco Leonardo Lisi, El tercer concilio limense y la aculturación de los indígenas sudamericanos, Salamanca, Universidad de Salamanca, 1990, 195.

17 Cf. Pilar Gonzalbo Aizpuru, "Las fiestas novohispanas: espectáculos y ejemplo", en Mexican Studies/Estudios Mexicanos IX:1, Irvine (CA), 1993, 19-45; Berta Ares Queija, "Las danzas de los indios: un camino para la evangelización del virreinato del Perú", en Revista de Indias XLIV:174, Madrid, 1984, 445-463; Juan Carlos Estenssoro, Música y sociedad coloniales. Lima, 1680-1830, Lima, Colmillo Blanco, 1989; del mismo autor, "Los bailes de los indios y el proyecto colonial", en Revista Andina X:2, Cuzco, 1992, 353-389.
} 
te lejos de concretar la aspiración de las autoridades ${ }^{18}$. Así, por ejemplo, a propósito de los indígenas de las cercanías rurales de Santiago, que se trasladaban cada año a la ciudad para participar en Corpus Christi, el jesuita Alonso de Ovalle señala que recorrían las calles inundando el espacio público con danzas y música, insertos en la gran procesión general que comprendía a todo el universo sociocultural de la ciudad: "Es tan grande el número de esta gente y tal el ruido que hacen con sus flautas y con la vocería de su canto, que es menester echarlos todos por delante, para que se pueda lograr la música de los eclesiásticos y cantores y podernos entender con el gobierno de la procesión" 19 .

Siendo las procesiones uno de los canales tradicionales a través de los cuales se expresaban las cofradías, ellas se transformaban en útil herramienta para el proceso de cristianización que se desplegó, en particular, sobre las poblaciones indígenas. Es en este contexto estratégico que podemos observar a las distintas órdenes de regulares que poblaron el espacio eclesiástico de la capital chilena esmerándose por apoyar la fundación y ostentar la existencia en su seno de cofradías que, al menos nominalmente, estaban diferenciadas por origen social o étnico. Corporaciones que podían verse desfilar por las calles durante la Semana Santa, en Corpus Christi y durante las respectivas festividades anuales de sus santos y advocaciones votivas ${ }^{20}$. No debe

18 Cf. Juan Carlos Estenssoro, "El simio de Dios. Los indígenas y la Iglesia frente a la evangelización del Perú, siglos XVI-XVIII”, en Bulletin de l'Institut Français d'Études Andines XXX:3, Lima, 2001, 455-474; del mismo autor, Del paganismo..., op. cit.; Carmen Bernand, "Los híbridos en Hispanoamérica. Un enfoque antropológico de un proceso histórico", en Guillaume Boccara y Silvia Galindo (eds.), Lógica mestiza en América, Temuco, Universidad de La Frontera, Instituto de Estudios Indígenas, 2000, 61-84; Carolyn Dean y Dana Leibsohn, "Hybridity and Its Discontents: Considering Visual Culture in Colonial Spanish America", en Colonial Latin American Review XII:1, Oxfordshire (UK), 2003, 5-35; Serge Gruzinski, La colonización de lo imaginario. Sociedades indígenas y occidentalización en el México español. Siglos XVI-XVIII, México, Fondo de Cultura Económica, 1991; del mismo autor, La guerra de las imágenes, México, Fondo de Cultura Económica, 1994; y "Cultural Interbreedings: Constituting the Majority as a Minority", en Comparative Studies in Society and History XXXIX:2, 1997, 231-250.

19 Alonso de Ovalle, Histórica relación del reino de Chile y de las misiones y ministerios que ejercita en él la Compañía de Jesús, Santiago, Universidad de Chile, Instituto de Literatura Chilena, 1969 [Roma, 1646], 185. Sobre la participación de indígenas urbanos en la fiesta del Corpus de otras ciudades coloniales, véase Serge Gruzinski, "La Fête-Dieu à Mexico au temps de la Nouvelle-Espagne", en Molinié, op. cit., 137-157; Linda Curcio-Nagy, "Giants and Gypsies: Corpus Christi in Colonial Mexico City", en William H. Bezzley et al., Rituals of Rule, Rituals of Resistence. Public Celebrations and Popular Culture in Mexico, Wilmington, Scholarly Resources Inc., 1994, 1-26; Carolyn Dean, Inka Bodies and the Body of Christ: Corpus Christi in Colonial Cuzco, Peru, Durham, Duke University Press, 1999.

20 Las fiestas religiosas del siglo XVII llegaban a ocupar 139 días del año, sin contar los domingos y las celebraciones extraordinarias: Sergio Villalobos, Historia del pueblo chileno, Santiago, ZigZag (vol. I-III) y Universitaria (vol. IV), 1983-2000: Vol. IV, 307-315. Véase nuestro trabajo Las liturgias del poder. Celebraciones públicas y estrategias persuasivas en Chile colonial (1609-1709), Santiago, DIBAM, Centro de Investigaciones Diego Barros Arana, Lom Ediciones, 2001, 148 y ss.; también, Benjamín Vicuña Mackenna, Historia de Santiago, en sus Obras completas, Santiago, Universidad de Chile, 1938, 353-354. Para un esquema general, aunque superficial: Isabel Cruz, La fiesta: Metamorfosis de lo cotidiano, Santiago, Universidad Católica de Chile, 1995. Existen varios trabajos sobre cofradías, mayoritariamente descriptivos, publicados en el Anuario de historia de la Iglesia en Chile: Ramón Ramírez, "La cofradía del Rosario en Chile" (10, 1992, 9-23); Misael Camus, "La Cofradía del Santísimo Sacramento de la Catedral de Santiago, 1682-1831” (10, 1992, 25-50); Antonio Rehbein, "La Ermita y Cofradía de San Clemente en San Juan de la Frontera. Siglo XVII" (10, 1992, 159-169); Jorge Falch, "Fundación de la Cofradía de Nuestra Señora del Rosario de Andacollo" (11, 
extrañar, por cierto, que el mayor peso demográfico relativo que tenía la población urbana de indígenas, "negros" y "castas"21, así como el papel asignado por la Iglesia a la cofradía "étnica" -como instancia de vivencia colectiva y vigilada del catolicismo y como canal devocional para la experiencia de la procesión penitencial- hayan determinado que fuesen las corporaciones integradas por dichos grupos quienes protagonizaran, por ejemplo, la mayoría de las catorce procesiones que circulaban por las calles de Santiago para Semana Santa, a mediados del siglo XVII, recordando la muerte de Jesús con autoflagelaciones, llantos y sonoros gemidos ${ }^{22}$.

1993, 149-176), Carlos Ruiz Rodríguez, "Cofradías en Chile Central. Un método de evangelización de la población indígena, mestiza y criolla” $(18,2000,23-58)$. Además, esta revista publicó una descripción y la transcripción de parte del libro de entradas y gastos de la cofradía de la Candelaria de San Agustín, incluyendo la nómina de cofrades para el período 1610-1651: Jorge Falch, "Cofradía de Nuestra Señora de la Candelaria de los mulatos en el Convento de San Agustín de Santiago de Chile", $1^{a}$ parte: $13,1995,17-30 ; 2^{a}$ parte: 16, 1998, 167-199. Contamos, también, con las tesis de licenciatura en historia de Akuarela Gutiérrez, La cofradía de encomenderos del Rosario (1590-1747): religiosidad y sociabilidad en la élite de Santiago colonial, Santiago, Pontificia Universidad Católica de Chile, 2000; y María Angélica Peralta, Religiosidad indígena en Santiago colonial (1640-1740), Santiago, Pontificia Universidad Católica de Chile, 2002; de esta última, "Las cofradías indígenas en Santiago colonial: más allá de un espacio", en www.identidades.uchile.cl; Alex Ovalle, "Una delgada línea entre lo material y lo espiritual: la Cofradía de la Limpia Concepción y Soledad de Nuestra Señora (1727-1797)", en Julio Retamal Ávila (coord.), Estudios coloniales IV, Santiago, Universidad Andrés Bello, 2006, 355-370.

21 Sobre la sociedad del Santiago de los siglos XVI y XVII, su composición étnica y la complejidad social y cultural que implicaban estas interacciones en el espacio urbano, véanse los trabajos de Armando de Ramón, "La sociedad española de Santiago de Chile entre 1581-1596 (Estudio de grupos)", en Historia 4, Santiago, 1965, 191-228; "Santiago de Chile, 1650-1700", en Historia 12, Santiago, 1974-75, 93-373, e Historia 13, 1976, 97-270; y Santiago de Chile (1541-1991). Historia de una sociedad urbana, Madrid, MAPFRE, 1992; Jean-Paul Zúñiga, Espagnols d'outre-mer. Émigration, métissage et reproduction sociale à Santiago du Chili, au 17 e siècle, París, Éditions de l'École des Hautes Études en Sciences Sociales, 2002. También, nuestros trabajos "Une société dépersonnalisée? Ordre colonial et référents identitaires à Santiago du Chili au XVII siècle", en Bernard Lavallé (ed.), Transgressions et stratégies du métissage en Amérique coloniale, París, Presses de la Sorbonne Nouvelle, 1999, 139-163; y “Afán de prestigio y movilidad social: los espejos de la apariencia”, en Rafael Sagredo y Cristián Gazmuri (eds.), Historia de la vida privada en Chile, Santiago, Taurus, I, 2005, 71-93. Sobre el universo propiamente indígena, hay aproximaciones a través de los trabajos de Patricio Cerda Carrillo, Mapuches de Mapocho. Aborígenes chilenos de Santiago de la Nueva Extremadura y sus regiones comarcanas, Tesis de Magíster en Historia, Universidad de Chile, Santiago, 1980; Carlos Ruiz Rodríguez, "Presencia de los mapuche-huilliche en Chile central en los siglos XVIXVIII. Desarraigo y mestizaje", en Boletín del Museo y Archivo Histórico Municipal de Osorno 4, Osorno, 1998, 1-71; Jaime Valenzuela Márquez, "Esclavos mapuches. Para una historia del secuestro y deportación de indígenas en la Colonia", en Rafael Gaune y Martín Lara (coords.), Historias de racismo y discriminación en Chile. Una mirada interdisciplinaria, Santiago, Uqbar Editores, 2009, 225-260. Sobre la complejidad del universo afromestizo, véase Jean-Paul Zúñiga, "Morena me 1laman'. Exclusión e integración de los afroamericanos en Hispanoamérica: el ejemplo de algunas regiones del antiguo virreinato del Perú (siglos XVI-XVIII)", en Berta Ares y Alessandro Stella (coords.), Negros, mulatos, zambaigos: derroteros africanos en los mundos ibéricos, Sevilla, Escuela de Estudios Hispano-Americanos, 2000, 105-122; William San Martín, "Presencias africanas en Chile. Circulaciones, relaciones pluriétnicas y emergencias culturales afromestizas. Siglos XVII-XVIII", en Seminario Simon Collier 2006, Santiago, Instituto de Historia, Pontificia Universidad Católica de Chile, 2006, 289-324; y los artículos del dossier coordinado por Celia Cussen, "Presencia africana en Chile colonial", Cuadernos de historia 25, Santiago, 2006. Cf., también, Arturo Grubessich, "Esclavitud en Chile durante el siglo XVIII: el matrimonio como una forma de integración social", en Revista de Historia 2, Concepción, 1992, 115-137.

22 Una descripción general de estas procesiones se encuentra en Villalobos, op. cit., III, 136-137. Una descripción de época en Ovalle, Histórica relación..., op. cit., 186 y ss. 
Estas formas devocionales no se limitaban, en todo caso, a la Semana Santa. De hecho, a escala menor, las formas tensionales e integrativas de esa festividad se repetían en buena parte del año. En los conventos y monasterios se organizaban, así, eventos similares para celebrar a "sus" santos, advocaciones y vírgenes ligadas específicamente a cada orden y a los patronos de sus cofradías; ceremonias que se sumaban a las propiamente diocesanas del calendario litúrgico anual, entre las que destacaba, como hemos dicho, la fiesta del Corpus Christi, a la cual también llegaban indígenas de las chacras cercanas a la ciudad:

\begin{abstract}
"Concurren a esta todas las religiones y cofradías con la solemnidad que se usa en otras partes, y todos los oficios mecánicos con sus estandartes y pendones, de manera que viene a coger muy grande trecho. Después de la procesión de la catedral se siguen las de las religiones y monasterios de monjas, con que vienen a durar todas más de un mes, procurando cada cual que salga mejor la suya, con mayor ostentación de cera y adorno de andas y altares, los cuales suelen hacerlos muy ricos y vistosos, de curiosas tramoyas y artificios. A todas estas procesiones acuden los indios de la comarca que están en las chacras (que son como aldeas, a una y dos leguas de la ciudad) y trae cada parcialidad su pendón, para el cual eligen algunos días antes el alférez, y este tiene obligación de hacer fiesta el día de la procesión a los demás de su ahillo"23.
\end{abstract}

Como vemos, el escenario de Santiago de Chile -periférico y modesto dentro del espacio virreinal, pero representativo de la diversidad étnica que caracterizaba al mundo urbano colonial- reprodujo el sistema de devoción corporativa que se desplegaba en el resto del continente, así como las prácticas religiosas que le estaban asociadas. Aquí, también, la cofradía se instituyó como un espacio de identidad corporativa y de posicionamiento social para los habitantes no hispanos. No obstante, como sucedía en la mayoría de estos procesos, ellos se desplegaron en medio de intercambios múltiples, desfases y transacciones, que romperían los esquemas más bien ideales diseñados por las autoridades administrativas e idealizados por los cronistas religiosos. Y será en este contexto donde podremos observar la integración específica de indígenas provenientes del espacio andino ${ }^{24}$, así como las relaciones pluriétnicas que subyacían a las procesiones descritas con anterioridad.

\title{
LA INMIGRACIÓN ANDINA: DESARRAIGO Y DIVERSIDAD
}

La presencia andina en Chile central tiene antecedentes que se vinculan con la fase expansiva del Tahuantinsuyu hacia el sur, cuando comenzaron a llegar colonias de mitimaes a asentarse en las riberas del río Mapocho -futuro enclave de la ciudad de Santiago-, con el fin de proteger el límite meridional del Imperio inca frente a la hostilidad de los indígenas que habitaban más al sur. Casi setenta años

23 Ovalle, Histórica relación..., op. cit.., 184-185.

24 Es necesario aclarar que al hablar de "los Andes", "espacio andino" o "indígenas andinos" estaremos haciendo referencia a las regiones vinculadas al virreinato peruano que hoy conforman los países de Perú, Bolivia y Ecuador. 
más tarde, cientos de yanaconas, provenientes de la región del Cuzco y de la meseta aymara del Collao -en las riberas del Titicaca-, acompañarían las expediciones de Diego de Almagro (1535) y luego de Pedro de Valdivia (1540), cargando alimentos y pertrechos y apoyando militarmente a los hispanos en su invasión de lo que más tarde se llamaría Chile 25 .

Como sirvientes, "soldados", traductores y concubinas, las andinas y los andinos fueron activos ayudantes de los europeos; y, si bien la coerción laboral sentó las bases iniciales de la relación entre ambos grupos, lo cierto es que su rápida acomodación a las obligaciones impuestas por los europeos, así como una actitud más bien pasiva y servil ayudaron a que tanto los indígenas locales como los propios españoles tendieran a verlos y a tratarlos como verdaderos "colaboradores" de la empresa. $\mathrm{Su}$ labor fue central desde un comienzo, extrayendo oro y trabajando los sembrados, cuando la encomienda de autóctonos aún se encontraba en su fase embrionaria, o auxiliando a los europeos en las refriegas contra los picunches del valle central ${ }^{26}$.

Hacia fines del siglo XVI ya se había consolidado la presencia de estos inmigrantes en el seno de la sociedad colonial. Así lo demuestra el análisis que hizo Álvaro Jara de unos 450 asientos de trabajo de indígenas y mestizos que se conservan en los registros de escribanos de Santiago para el período 1586-1600 (más algunos fragmentos documentales para $1565,1566,1578,1580$ y 1585). Ciertamente, en dichos registros predominan los indígenas originarios del sur de Chile (44\%), cuyo peso demográfico era evidente en la capital, si consideramos la temprana y masiva deportación que sufren bajo una velada esclavitud o mediante el traslado arbitrario de yanaconas y "chinas" de servicio desde el mundo fronterizo de la Araucanía, la zona de Valdivia o la isla de Chiloé. A ellos le siguen tres grupos con cantidades equivalentes: los asentados juríes del Tucumán (10\%), los originarios de la propia capital (10\%) y los andinos, con cerca del $9 \%$ de los asientos, equivalente a 34 personas $^{27}$.

25 Alonso de Góngora Marmolejo, "Historia de Chile desde su descubrimiento hasta el año de 1575", en Francisco Esteve Barba (ed.), Crónicas del reino de Chile, Madrid, Biblioteca de Autores Españoles, CXXXI, 1960, 80; Pedro Mariño de Lobera, "Crónica del Reino de Chile, escrita por el capitán D. Pedro Mariño de Lobera..., reducido a nuevo método y estilo por el padre Bartolomé de Escobar, de la Compañía de Jesús" [1580], en ibid., 241; Carta de Pedro de Valdivia a Hernando Pizarro (La Serena, 4 de septiembre de 1545), en Cartas de don Pedro de Valdivia que tratan del descubrimiento y conquista de la Nueva Extremadura, Santiago-Barcelona, Editorial Andrés Bello, Lumen, 1991, 83; Diego Barros Arana, Historia general de Chile, Santiago, Editorial Universitaria, DIBAM, Centro de Investigaciones Diego Barros Arana, 1999-2005 [1884-1902], I, 137; Villalobos, op. cit., I, 194. Cf. Ricardo Piqueras, “Un indio vale casi como un caballo': utilización indígena de las huestes del siglo XVI”, en Boletín americanista 46, Barcelona, 1996, 275-297.

26 Osvaldo Silva, "Aproximaciones al estudio del mestizaje en Chile entre los siglos XVI y XVII", en Sonia Pinto (ed.), Familia, matrimonio y mestizaje en Chile colonial, Santiago, Universidad de Chile, Facultad de Filosofía y Humanidades, Serie "Nuevo Mundo: cinco siglos", 1990, 22.

27 La importancia de la zona de "los juríes", cuyo nombre apuntaba a un espacio más bien genérico, ligado a la zona del Tucumán y centrado en la ciudad de Córdoba, respondería, según el autor, a que esta última era una ciudad que servía de escala importante para los circuitos comerciales que unían a Buenos Aires con Santiago; circuitos que alimentarían, también, las circulaciones de indígenas, quizás acompañando a las caravanas con productos: Álvaro Jara, "Los asientos de trabajo y la provisión de mano de obra para los no-encomenderos en la ciudad de Santiago, 1586-1600" [1959], en Álvaro Jara (comp.), Trabajo y salario indígena. Siglo XVI, Santiago, Universitaria, 1987, 59-63. 
Estas proporciones laborales son coherentes con las proporciones demográficas aportadas por el informe que, algunos años más tarde, en 1614, elaboró el licenciado Hernando Machado, oidor de la Audiencia de Chile, dando cuenta de los indígenas establecidos en los arrabales de la capital. Aquí aparecen los indios provenientes de Perú y Tucumán -que el letrado enumera en conjunto- con 225 personas, equivalentes al $17 \%$ del total de indígenas de la ciudad ${ }^{28}$.

En todo caso, en los testamentos que varios de los inmigrantes andinos dictaron algunas décadas más tarde, observamos un origen geográfico bastante más variado que el de los acompañantes de los conquistadores. Esta evidencia nos permite creer que, luego de aquella primera corriente masiva de mediados del siglo XVI, se habría dado un movimiento más individual, que atrajo a Chile a personas procedentes de lugares tan disímiles como Huamanga, Huánuco, Jauja, Arequipa, Cochabamba e incluso Quito y Guayaquil ${ }^{29}$.

Las huellas que han dejado estos inmigrantes en los archivos chilenos, si bien son muchas veces fragmentarias, permiten generar una serie de hipótesis en torno al proceso que vivieron. Podemos pensar, así, que estamos en presencia de sujetos marcados por una gran experiencia de desarraigo. Situación vinculada, en primer lugar, a la condición de inmigrante propiamente tal, que supone el alejamiento -generalmente definitivo- de su espacio geográfico de origen, así como el traslado y, luego, el proceso de asentamiento e inserción en el lugar de destino. En segundo lugar, al menos para aquellos que no vinieron en los traslados masivos de las expediciones conquistadoras, la individualidad con la que vivieron este proceso, que implicó, a su vez, un quiebre personal con la comunidad de origen y la eventual pérdida de lazos sociales y culturales con sus miembros. En tercer lugar, el cambio fundamental que conllevó dejar el espacio rural y aldeano y asentarse en la complejidad de una ciudad, independientemente de si esta era más bien modesta en sus pretensiones urbanas, como Santiago de Chile. Por último, este desarraigo envuelve la necesidad vital de "rearraigarse", de construir nuevos lazos sociales y nuevas redes materiales en el lugar de asentamiento. Proceso tanto más claro en el caso de sus descendientes, que transportaron una "memoria familiar foránea" y, al mismo tiempo, una "experiencia personal local".

\section{COFRAdíAS Y ADVOCACIONES DE LOS “CUZCOS” DE SANTIAGO}

En el contexto antes señalado, cabe preguntarse entonces sobre el papel que cupo a las cofradías en el rol tradicional que hemos visto al comienzo. Vale decir, como instancia de cohesión y de identidad social, como expresión de religiosidad y como referente de integración y de prestigio. En otras palabras, en qué medida las

28 El informe de Machado lo recoge Antonio Vázquez de Espinosa, Compendio y descripción de las indias occidentales [ca. 1629], Madrid, Biblioteca de Autores Españoles, CCXXXI, 1969, 45 (párrafos 1933 y 1934).

29 Julio Retamal Ávila, Testamentos de “indios” en Chile colonial: 1564-1801, Santiago, Universidad Andrés Bello, RIL, 2000. 
cofradías sirvieron como canales para integrar a la vida urbana -en particular- y al sistema colonial -en general-, a dichos individuos inmigrantes; en segundo lugar, en qué forma estas corporaciones alimentaron una virtual identificación "panandina" en situación de inmigración; y, por último, bajo qué condiciones ellas fueron, también, un reflejo de las relaciones interétnicas y pluriculturales que se tejían en aquel espacio urbano.

Este último aspecto es fundamental, toda vez que la realidad santiaguina dista mucho de aquel tipo de cofradía establecida por el clero en el seno de los pueblos indígenas andinos, asociada a la comunidad como unidad étnica y vinculada económicamente con sus bienes, los que muchas veces llegaban a confundirse. Más allá de que estas cofradías incluyeran a otros actores -en el caso de que hubiese españoles residentes-, sin duda ellas otorgaron un nuevo sentido de pertenencia y de cohesión social a la comunidad, actuando -según lo indicamos antes- como un mecanismo de adaptación en medio de los intensos cambios sufridos durante las décadas posteriores a la conquista, con la crisis de identidad política -por el quiebre del Estado inca-, la reorganización colonial del trabajo, del tributo y de los factores productivos, la militancia cristianizadora de la Iglesia, etc. ${ }^{30}$.

En la capital chilena estamos muy lejos de esa realidad cofradial "comunitaria", pues, como hemos visto, no observamos ninguna unidad étnica específica entre los andinos inmigrantes. Más aún, insistimos, aquellos para los cuales disponemos de información precisa son en su mayoría individuos que, generalmente, no contemplan ningún vínculo étnico ni geográfico de origen entre ellos, salvo el hecho de ser inmigrantes y de provenir del espacio andino.

Lo que sí está claro es que, en forma similar a lo sucedido en otras partes de América, los diversos segmentos de la sociedad colonial -y los indígenas en particular- recibieron el sistema de cofradías como un hecho positivo, incorporándolo de inmediato y con energía a sus prácticas sociales y religiosas. En el caso chileno, por cierto, ellas se erigieron como un soporte de integración, reconocimiento y movilidad para los actores de aquella sociedad escindida y plural ${ }^{31}$.

El problema historiográfico presentado es tan complejo como la realidad social analizada. Nuestra intención, entonces, será la de dar algunos indicios y presentar avances de investigación que permitan explorar estos procesos, a la luz de las fuentes consultadas hasta el momento.

Una primera línea de aproximación empírica al tema está dada por la existencia de una serie de testamentos y contratos de trabajo -asientos-. Se trata, evidentemente, de una fuente de carácter fragmentario, toda vez que no da cuenta de la totalidad de los indígenas involucrados sino solo de aquellos que dejaron su huella al dictar sus últimos deseos o fijar determinadas obligaciones laborales en los registros notariales de la capital chilena. En el caso de los testamentos, por cierto, estamos frente a individuos que han logrado cierta autonomía material, como artesanos y propietarios de solares suburbanos, donde normalmente cultivan frutales,

30 Bazarte, Las cofradías..., op. cit., 44-45; Celestino y Meyers, Las cofradías..., op. cit., 35 y 43.

31 Bechtloff, Las cofradías..., op. cit., 217; Ruiz Rodríguez, "Cofradías...”, op. cit., 30. 
olivos y viñedos. En este sentido, como apunta Pablo Rodríguez, es un grupo que representa a los indígenas más integrados a la sociedad colonial y a sus prácticas administrativas, a tal punto que recurren al mecanismo occidental del testamento para dejar testimonio escrito -con validez jurídica- de sus deseos y herencias, materiales e inmateriales ${ }^{32}$. Su débil representatividad cuantitativa se hace más evidente si consideramos que para el período estudiado apenas contamos con una veintena de estos documentos dictados por actores andinos. Además, varios de ellos corresponden al siglo XVI, cuando aún no existían las cofradías a las que nos referiremos, y que los agruparán más tarde, desde la primera década de la centuria siguiente $^{33}$. Así, por ejemplo, al menos ocho de los once testamentos de andinos que no mencionan su pertenencia a una cofradía fueron dictados durante ese período previo.

En esta misma línea preventiva, debemos estar atentos a la frecuente sobredimensión que hace el historiador de su objeto de estudio específico, magnificando cualidades y proyecciones impresionistas que no siempre coinciden con las dimensiones reales que muestran las fuentes. De esta forma, y como lo veremos a continuación, es necesario relativizar y matizar la capacidad de convocatoria y el rol integrador de las cofradías estudiadas, toda vez que no aparecen como instancias masivas y solo las vemos integradas por algunas decenas de los miles de indígenas, morenos y castas que poblaban la ciudad en la época estudiada. Conviene recordar aquí que a comienzos del siglo XVII la población no hispanocriolla de la capital -incluyendo su jurisdicción próxima- era de unas 9.000 personas, entre indígenas, negros y castas, entre los cuales se contaban alrededor de 1.500 indios tributarios; a ellos se agregaban unos 2.000 hispanocriollos. Para mediados del siglo, el total de la población del radio propiamente urbano sería de unas 5.000 personas $^{34}$.

32 Pablo Rodríguez Jiménez (ed.), Testamentos indígenas de Santafé de Bogotá, siglos XVI-XVII, Bogotá, Alcaldía Mayor de Bogotá, Instituto Distrital de Cultura y Turismo, 2002, 17. Sobre el papel del testamento indígena en el contexto de la sociedad colonial urbana, en la construcción de redes sociales, herencias materiales y economías espirituales, véase el trabajo de Jacques Poloni Simard, "Testamentos indígenas e indicadores de transformación de la sociedad indígena colonial (Cuenca, siglo XVII)", en Thérèse Bouysse-Cassagne (ed.), Saberes y memorias en los Andes. In memoriam Thierry Saignes, París-Lima, CREDAL, IFEA, 1997, 279-299. Muy importantes son también los trabajos compilados por Susan Kellogg y Matthew Restall (eds.), Dead Giveaways. Indigenous Testaments of Colonial Mesoamerica and the Andes, Salt Lake City, University of Utah Press, 1998.

33 Ello, pese a que ya en el XVI se habían fundado las órdenes religiosas respectivas: los mercedarios se establecieron en Santiago en 1548, los franciscanos en 1553, los dominicos en 1557, los jesuitas en 1593 y los agustinos en 1595. Los hospitalarios de San Juan de Dios se hicieron cargo del hospital de Santiago recién en 1617.

34 Informe del oidor Gabriel de Celada (1610), citado en Crescente Errázuriz, Historia de Chile durante los gobiernos de García Ramón, Merlo de la Fuente y Jaraquemada, Santiago, Imprenta Cervantes, 1908, II, 21; Informe del oidor Hernando Machado (1614), citado en Vázquez de Espinosa, Compendio..., op. cit., 45; De Ramón, Santiago de Chile..., op. cit., 75; Zúñiga, Espagnols..., op. cit., 94-96. Según los registros parroquiales de bautismos de la parroquia del Sagrario, para el período 1581-1596 se contarían 366 niños "españoles", 1.313 "indígenas" y unos 120 morenos (negros, mulatos y zambos); para el período 1641-1663, se contarían poco más de 1.000 niños "españoles", casi 800 "indígenas" y más de 900 morenos: Armando de Ramón, "Bautizos de indígenas según los libros del Sagrario de Santiago correspondientes a los años 1581-1596”, Historia 4, Santiago, 1965, 230; Zúñiga, Espagnols..., op. cit., 178 


\section{CUADRO ${ }^{\circ} 1$}

\section{INDÍGENAS ANDINOS Y SU RELACIÓN CON COFRADÍAS Y ESTABLECIMIENTOS RELIGIOSOS EN EL MOMENTO DE TESTAR (SANTIAGO DE CHILE, 1564-1700)}

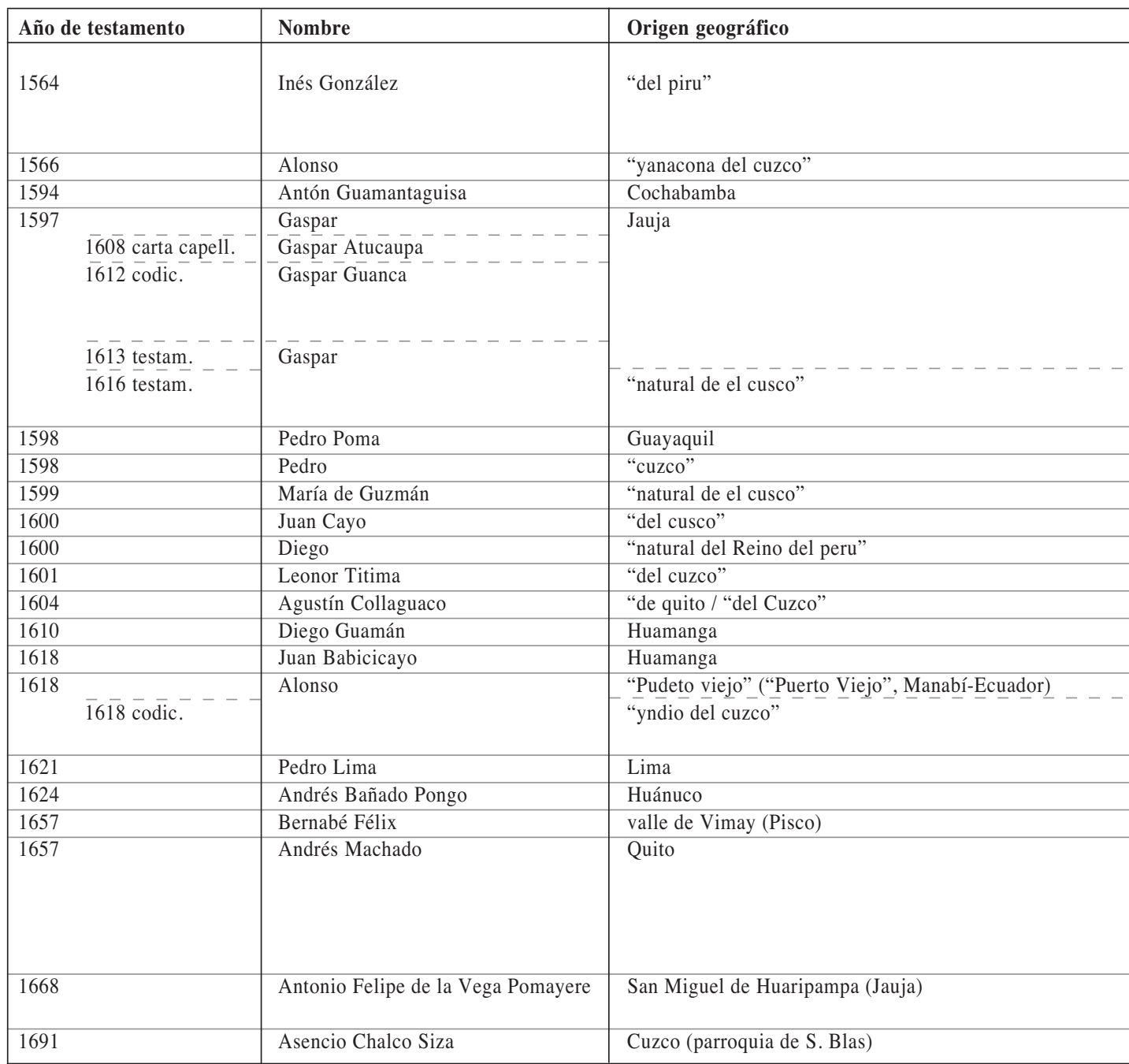

* Encargo de misas, capellanías, legado de bienes, etc.

** El altar de San José se encontraba a la derecha del altar mayor, sobre la tumba del obispo Diego de Medellín (†1593), y albergaba un tabernáculo con el bulto del santo. La vinculación del santo con el obispo Medellín se debía a que este había sido un activo promotor de su devoción, particularmente entre los neófitos indígenas y morenos, presentándolo como un modelo paternal y casto de vida personal, marital y familiar. Su mismo oficio de carpintero lo convirtió, por lo demás, en una figura de referencia para los artesanos urbanos. Su culto individual surgió en el siglo XVI gracias a Teresa de Ávila y se desplegó bajo la influencia de la Compañía de Jesús, llegando a ser declarado 


\begin{tabular}{|c|c|c|c|}
\hline Oficio & Cofradía & Lugar de entierro & Otra vinculación religiosa ${ }^{*}$ \\
\hline & $\begin{array}{l}\text {-Smo. Sacramento (catedral) } \\
\text {-Veracruz (la Merced) } \\
\text {-Ntra. Sra. del Socorro (S. Fco) }\end{array}$ & S. Francisco & $\begin{array}{l}\text {-La Merced } \\
\text {-Catedral }\end{array}$ \\
\hline & & S. Francisco & \\
\hline & & La Merced & Capilla de S. Saturnino \\
\hline albañil & Guadalupe & $\begin{array}{l}\text { Sto. Domingo } \ldots-\ldots \\
-\ldots-- \\
\text { La Merced } \\
\text { Sto. Domingo - - - - - }\end{array}$ & 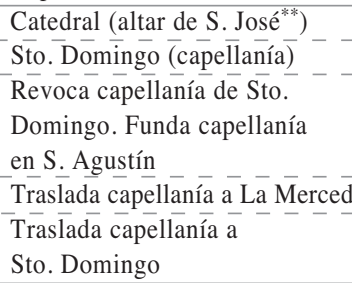 \\
\hline sastre (?) & "de la compañya de Jesus" & S. Agustín & \\
\hline & & Catedral & \\
\hline & & Hospital S. Juan de Dios & Catedral (altar de S. José) \\
\hline & & La Merced & Catedral \\
\hline & & Hospital S. Juan de Dios & \\
\hline & & S. Francisco & \\
\hline sedero / sombrerero & & S. Agustín & Catedral (altar de S. José) \\
\hline & Guadalupe & La Merced & \\
\hline sastre (?) & Guadalupe & La Merced & \\
\hline carpintero & Guadalupe & S. Francisco & La Merced \\
\hline & & $\begin{array}{l}\text { La Merced } \\
\text { (capilla de Guadalupe) }\end{array}$ & \\
\hline sastre & & S. Agustín & \\
\hline sedero / sombrerero (?) & Candelaria & S. Agustín & \\
\hline sastre & & Catedral (arco de pobres) & \\
\hline zapatero & $\begin{array}{l}\text {-Copacabana (fue mayordomo) } \\
\text {-San Crispín (La Merced) } \\
\text { (fue mayordomo) } \\
\text {-N. Sra. de las Nieves } \\
\text { (La Merced) (fue mayordomo) }\end{array}$ & S. Francisco & \\
\hline $\begin{array}{l}\text { sombrerero, tintorero } \\
\text { y comerciante }\end{array}$ & Guadalupe & La Merced (capellanía) & \\
\hline & & Catedral & Sto. Domingo \\
\hline
\end{tabular}

patrón de México en 1555: Gaston Duchet-Suchaux y Michel Pastoureau, La Bible et les saints. Guide iconographique, París, Flammarion, 1994, 204-205; Emma de Ramón, "Artífices negros, mulatos y pardos en Santiago de Chile: siglos XVI y XVII", Cuadernos de historia 25, Santiago, 2006, 70-71.

Fuente: Retamal, Testamentos..., op . cit., passim; Álvaro Jara y Rolando Mellafe (comps.), Protocolos de los escribanos de Santiago. Primeros fragmentos, 1559 y 1564-1566, Santiago, DIBAM, Centro de Investigaciones Diego Barros Arana, 1996, II, 684; ANH.ES, vol. 6, fjs. 251-251v; vol. 13, fjs. 294294v; vol. 14, fjs. 158-159v; vol. 19, fjs. 51v-53; vol. 27, fjs. 320-320v; vol. 38, fjs. 199-199v; vol. 49, fjs. 257-258; vol. 80, fjs. 190-191v; vol. 81, fjs. 309v-310; vol. 87, fjs. 132-133v. 
No obstante todo lo anterior, pensamos que los fragmentos testamentarios y contractuales utilizados en nuestro trabajo mantienen su validez como sustento interpretativo de procesos sociales y culturales más amplios, al entregarnos numerosas y variadas señales que Carlo Ginzburg legitimó a través de su "paradigma indiciario". Según este, es válida la construcción de conocimiento a partir de las huellas, rastros o síntomas dispersos en las fuentes históricas, brindando de esta manera una suerte de solución de continuidad cualitativa para el historiador que no tiene acceso a aquel cúmulo de información sistemática y cuantitativa que le permitiría generalizaciones macrosociales ${ }^{35}$. Las experiencias individuales y aisladas que nos muestran los testamentos y asientos notariales, confrontadas con otros fragmentos de vidas individuales y de contextos socioculturales vinculados con la diacronía que dinamiza el fenómeno estudiado, podrían, entonces, ayudarnos a explorar tendencias más generales ${ }^{36}$.

De esta forma, los testamentos que dictaron algunos de estos inmigrantes andinos permiten detectar sus preferencias entre la variedad de asociaciones que ofrecían las iglesias y conventos locales y, por lo mismo, percibir ciertas dinámicas y sacar algunas conclusiones preliminares. A continuación, incluimos un cuadro donde se detallan las personas de origen andino que testaron en el período, el origen geográfico y oficio que declararon, la cofradía a la que pertenecían en ese momento, el lugar sagrado donde deseaban ser enterrados y las vinculaciones adicionales que aparecen con otros establecimientos religiosos, generalmente por las misas encargadas para después de su muerte.

Una primera observación que podemos extraer de este cuadro es, como ya lo habíamos adelantado, la variedad geográfica de los testantes: Cuzco, Lima, Cochabamba, Jauja (Junín), Guayaquil, Quito, Huamanga (Ayacucho), Puerto Viejo (Manabí-Ecuador), Huánuco y Pisco.

En segundo lugar, por las fechas de sus testamentos, podemos aventurar la hipótesis de que la mayoría de ellos no correspondería a aquellos yanaconas que llegaron masivamente con los primeros conquistadores, sino que más bien serían inmigrantes individuales, de los cuales desconocemos, por el momento, sus motivaciones y circuitos. Ello podría explicar, pensamos, la dispersión relativa de su origen específico. Otra hipótesis es que estos andinos sí hayan sido parte de aquella inmigración "originaria", siendo muy niños y acompañando a sus padres, lo cual podría ser válido para los testantes anteriores a 1600 -considerando un máximo de sesenta años desde la llegada de Pedro de Valdivia-. De ser cierto, podrían corresponder a personas desplazadas previamente al Cuzco desde otras regiones y luego integradas a las expediciones conquistadoras, pues la mayoría no tienen relación con el Collao, la otra región que alimentó con yanaconas a las huestes del siglo XVI.

35 Carlo Ginzburg, "Indicios. Raíces de un paradigma de inferencias indiciales" [1979], en $M i$ tos, emblemas, indicios. Morfología e historia, Barcelona, Gedisa, 1989; del mismo autor, "Huellas. Raíces de un paradigma indiciario" [1979] e "Intervención sobre el "paradigma indiciario"” [1980], en Carlo Ginzburg, Tentativas, Rosario, Prohistoria, 2004, 69-127.

36 Sobre la conjetura como herramienta narrativa útil al momento de pretender dar cuenta de procesos tan complejos como fragmentarios, véase Claudio Rolle, "La ficción, la conjetura y los andamiajes de la historia", Documento de Trabajo $n^{\circ} 2$, Santiago, Pontificia Universidad Católica de Chile, Instituto de Historia, 2001. 
Una tercera tendencia que podemos observar en la información del cuadro es la preponderancia de la cofradía de Nuestra Señora de Guadalupe, establecida en la iglesia de La Merced, con una mayor concentración de testantes andinos en la segunda década del siglo XVII. Junto con ella, también son mencionadas otras dos cofradías: la de Nuestra Señora de Copacabana -establecida en la iglesia de San Francisco- y la de la Nuestra Señora de la Candelaria -en San Agustín-. Si bien es cierto las dos últimas solo aparecen en una oportunidad, podemos ampliar su valoración andina si observamos la elección de cofradías que mencionan sus descendientes "criollos" -muchos de ellos mestizos-, según la tabla de testantes que adjuntamos a continuación.

\section{CUADRO $\mathrm{N}^{\circ} 2$}

DESCENDIENTES DE INDÍGENAS ANDINOS Y SU RELACIÓN CON COFRADÍAS Y ESTABLECIMIENTOS RELIGIOSOS EN EL MOMENTO DE TESTAR (SANTIAGO DE CHILE, 1564-1700)

\begin{tabular}{|c|c|c|c|c|c|c|}
\hline \begin{tabular}{|l|} 
Año de \\
testamento
\end{tabular} & Nombre & $\begin{array}{l}\text { Ascendiente } \\
\text { andino }\end{array}$ & Oficio & Cofradía & $\begin{array}{l}\text { Lugar } \\
\text { de entierro }\end{array}$ & $\begin{array}{l}\text { Otra } \\
\text { vinculación } \\
\text { religiosa }\end{array}$ \\
\hline 1589 & $\begin{array}{l}\text { Isabel } \\
\text { de Gálvez }\end{array}$ & $\begin{array}{l}\text { Hija de india } \\
\text { de Quito }\end{array}$ & & & S. Francisco & \\
\hline 1590 & $\begin{array}{l}\text { Beatriz } \\
\text { Méndez }\end{array}$ & $\begin{array}{l}\text { Hija de } \\
\text { "yndia del peru" }\end{array}$ & & & Sto. Domingo & \\
\hline 1591 & Catalina & $\begin{array}{l}\text { "yndia del cuzco } \\
\text { naçida en esta tierra" }\end{array}$ & & & Catedral & \\
\hline 1602 & Mayora & $\begin{array}{l}\text { hija de "cuzco" (y } \\
\text { viuda de Juan Cayo) }\end{array}$ & & & S. Agustín & Catedral \\
\hline 1602 & $\begin{array}{l}\text { Juan de } \\
\text { Azoca }\end{array}$ & $\begin{array}{l}\text { Hijo de india "de el } \\
\text { piru" y de encomende- } \\
\text { ro Santiago de Azoca }\end{array}$ & & & $\begin{array}{l}\text { Catedral (capilla } \\
\text { de su padre) }\end{array}$ & $\begin{array}{l}\text { Todos los } \\
\text { conventos y } \\
\text { colegio } \\
\text { jesuita }\end{array}$ \\
\hline 1612 & Rodrigo & $\begin{array}{l}\text { Coquimbo; "natural } \\
\text { de Quispecancha" } \\
\text { (Quispicanchis, Cuzco) }\end{array}$ & albañil & Guadalupe & La Merced & \\
\hline 1613 & $\begin{array}{l}\text { Diego } \\
\text { (de Castro?) }\end{array}$ & $\begin{array}{l}\text { hijo de "indios } \\
\text { del cuzco" }\end{array}$ & sastre & Guadalupe & La Merced & \\
\hline 1619 & $\begin{array}{l}\text { Lorenzo } \\
\text { Ramírez } \\
\text { Yáñez }\end{array}$ & $\begin{array}{l}\text { Hijo de "yndia } \\
\text { cuzca" }\end{array}$ & sastre (?) & Candelaria & S. Agustín & \\
\hline 1626 & Francisca & $\begin{array}{l}\text { Hija de "yndio } \\
\text { del cusco" }\end{array}$ & & & La Merced & \\
\hline 1639 & Ana Jauja & $\begin{array}{l}\text { Hija de Gaspar } \\
\text { Guanca }\end{array}$ & partera (?) & Copacabana & S. Francisco & \\
\hline
\end{tabular}

Fuente: Retamal, Testamentos..., passim; ANH.ES, vol. 5, fjs. 102-103; vol. 6, fjs. 9-10v; vol. 30, fjs. 7-8v; vol. 51, fjs. 210v-211v; vol. 60, fjs. 9-9v. 


\section{CUADRO $\mathrm{N}^{\circ} 3$}

\section{OTROS INDÍGENAS Y SU RELACIÓN CON COFRADÍAS Y ESTABLECIMIENTOS RELIGIOSOS EN EL MOMENTO DE TESTAR (SANTIAGO DE CHILE, 1564-1700)}

\begin{tabular}{|c|c|c|}
\hline Año de testamento & Nombre & Origen geográfico \\
\hline 1596 & Catalina & Angol \\
\hline 1596 & Bartolomé & Valdivia \\
\hline 1597 & Hernando Chipanvilu & cacique de Tango \\
\hline 1597 & Magdalena & "natural desta tierra" \\
\hline 1597 & Inés & Lihüeimo (Colchagua) \\
\hline 1606 & Teresa Gudines & "natural desta tierra" \\
\hline 1608 & Alonso Rodríguez & Tucumán \\
\hline 1610 & Inés de Berrío & "natural de esta tierra" \\
\hline 1610 & Bárbola de Oropeza & viuda del cacique de Macul \\
\hline 1610 & Juana & La Imperial \\
\hline 1613 & Pedro & Villarrica \\
\hline 1617 & Hernando & "natural de esta tierra" \\
\hline $1617 \overline{161 \overline{7}}--$ & Juan Obispo & "natural desta provincia" \\
\hline 1618 & Juana & Santiago (hija de caciques de Quillota) \\
\hline 1619 & Miguel & Valdivia \\
\hline 1624 & María de Barros & Lampa \\
\hline 1631 & Ana Vebún & "natural de la probincia de chilue" \\
\hline 1631 & Lorenza de Cárdenas & Santiago \\
\hline 1636 & Isabel de Agurto & Santiago \\
\hline 1644 & María de Ahumada & Córdoba de Tucumán (c/c Pedro Durán, indio de Potosí) \\
\hline 1645 & Luisa de Araya & (c/c “cusco” Francisco de Cháves) \\
\hline 1646 & Constanza de Escobar & Santiago \\
\hline 1647 & Catalina de Sierra & "yndia ladina ... moradora en esta ciudad" \\
\hline 1651 & Catalina de Guevara & La Imperial \\
\hline 1660 & María de Otavio & "yndia ladina moradora de esta zivdad" \\
\hline 1661 & Lucas Barros & Lampa \\
\hline 1662 & Leonor & \\
\hline 1666 & Tomás Robles & Arauco \\
\hline 1671 & Constanza de Aguilera & Concepción \\
\hline 1676 & Magdalena de Araya & Santiago \\
\hline 1682 & Pascual de Jesús & Santiago \\
\hline 1692 & Melchora Rodulfo & Rapel \\
\hline
\end{tabular}

* Encargo de misas, capellanías, legado de bienes, etc.

Fuente: Retamal, Testamentos..., passim; Raïssa Kordic (ed.), Testamentos coloniales chilenos, Madrid, Iberoamericana/Vervuert, 2005, 302-305; Ruiz, "Cofradías en Chile Central...", op. cit., 45; ANH.ES, vol. 45, fjs. 494-494v. 


\begin{tabular}{|c|c|c|c|}
\hline Oficio & Cofradía & Lugar de entierro & Otra vinculación religiosa* \\
\hline & & S. Francisco & \\
\hline zapatero & & La Merced & \\
\hline & & La Merced & $\begin{array}{l}\text {-Catedral } \\
\text {-La Merced (capellanía) }\end{array}$ \\
\hline costurera o bordadora (?) & & S. Francisco & \\
\hline & & Catedral (arco de pobres) & Catedral (altar de S. José) \\
\hline & & S. Francisco & \\
\hline sastre (?) & Copacabana & S. Francisco & \\
\hline & & La Merced & Catedral (altar de S. José) \\
\hline & & Catedral (arco de pobres) & \\
\hline & Candelaria & S. Agustín & \\
\hline carpintero & Copacabana & S. Francisco & \\
\hline zapatero & & $\begin{array}{l}\text { La Merced } \\
\text { (capilla de la Veracruz) }\end{array}$ & \\
\hline albañil & & $\begin{array}{l}\text { Catedral } \\
\text { Hospital S. Juan de Dios }\end{array}$ & \\
\hline & & Hospital S. Juan de Dios & \\
\hline sastre & Guadalupe & La Merced & \\
\hline & Guadalupe (?) & Hospital S. Juan de Dios & La Merced \\
\hline & Copacabana (fundadora) & S. Francisco & \\
\hline & & Sto. Domingo & S. Francisco \\
\hline & Guadalupe & La Merced & \\
\hline costurera o bordadora (?) & Guadalupe & La Merced (capellanía) & \\
\hline & Guadalupe & La Merced & \\
\hline & Guadalupe & La Merced & \\
\hline costurera o bordadora (?) & $\begin{array}{l}\text {-Copacabana } \\
\text {-Candelaria }\end{array}$ & S. Francisco & \\
\hline & & S. Francisco & \\
\hline & & Compañía de Jesús & \\
\hline & & S. Francisco & \\
\hline & & S. Francisco & \\
\hline zapatero & Del Niño Jesús & Compañía de Jesús & \\
\hline & Jesús Nazareno & La Merced & \\
\hline & Jesús Nazareno & La Merced & \\
\hline sastre & $\begin{array}{l}\text {-Copacabana } \\
\text {-Nra. Sra. de Renca } \\
\text { (procurador) } \\
\text { (Parroquia de Renca) }\end{array}$ & S. Francisco & \\
\hline & Copacabana & S. Francisco & \\
\hline
\end{tabular}


Ya tenemos, entonces, las principales cofradías donde se asientan, sociabilizan, celebran, ahorran y se entierran la mayoría de los inmigrantes indígenas que provienen del espacio andino y sus descendientes. No obstante, y avanzando en el objetivo de nuestra demostración, observamos que dichos espacios no eran exclusivos de este grupo. Al contrario, también aparecen como las cofradías preferidas por otros indígenas, tanto locales como inmigrantes de otros lugares de Chile, como se puede apreciar en el siguiente cuadro.

Como vemos, de un total de 16 testantes indígenas no andinos que mencionan su pertenencia a una cofradía, prácticamente todos se distribuyen entre la de Guadalupe (6), la de Copacabana (6) y la Candelaria (2). Incluso vemos entre ellos a una fundadora de la de Copacabana (la chilota Ana Vebún, que testa en 1631) y a otra indígena que comparte su pertenencia entre esa cofradía franciscana y la Candelaria agustina (Catalina Sierra, que testa en 1647).

El panorama puede quedar más claro si observamos un resumen de los cuadros anteriores:

\section{CUADRO $\mathrm{N}^{\circ} 4$}

PERTENENCIA A COFRADÍAS EN EL MOMENTO DE TESTAR (SANTIAGO DE CHILE, 1564-1700)

\begin{tabular}{lcccc}
\hline & Andinos & Descendientes & Otros indios & Total de asientos \\
\hline Guadalupe & 5 & 2 & 6 & 13 \\
Copacabana & 1 & 1 & 6 & 8 \\
Candelaria & 1 & 1 & 2 & 4 \\
Otras & 3 & - & 4 & 7 \\
Sin cofradía & 11 & 6 & 16 & 33 \\
& & & & 65 \\
\hline
\end{tabular}

A ello podríamos agregar las tendencias observadas en la preferencia que manifiestan los indígenas al momento de decidir donde desean ser sepultados. Esta información confirma, así, la cercanía devocional e institucional que tenían -al menos los testantes estudiados- con los conventos y órdenes religiosas asociadas a esas mismas cofradías, en cuyos templos probablemente habían practicado su religiosidad en vida, aunque no pertenecieran formalmente a alguna de dichas corporaciones:

\section{CUADRO $\mathrm{N}^{\circ} 5$}

LUGAR DE ENTIERRO, SEGÚN TESTAMENTO

(SANTIAGO DE CHILE, 1564-1700)

\begin{tabular}{lcccc}
\hline & Andinos & Descendientes & Otros indios & Total \\
\hline La Merced & 6 & 3 & 11 & 20 \\
S. Francisco & 4 & 2 & 12 & 18 \\
S. Agustín & 4 & 2 & 1 & 7 \\
Otro lugar & 6 & 3 & 8 & 17 \\
& & & & 62 \\
\hline
\end{tabular}


Como vemos, las tres cofradías -todas ellas marianas, por cierto- donde se concentraba la sociabilidad religiosa de los andinos eran, en el fondo, espacios donde confluían personas de muy diverso origen geográfico y cultural, aunque todas marcadas por la categoría colonial de "indígena".

\section{Nuestra SEÑORA DE GuAdalupe}

La cofradía que concentra la preferencia de los inmigrantes andinos probablemente tuvo su origen en el periplo que cumplió el monje jerónimo Diego de Ocaña, del monasterio español de Nuestra Señora de Guadalupe, y que se inscribió en el desarrollo que tuvo la orden durante el reinado de Felipe II $^{37}$. Ocaña arribó a Lima en 1599 con la intención de difundir, a nivel continental, el culto a esta advocación y, en especial, a su imagen, a través de unos siete retratos que pintó, intentando reproducir la escultura original, y que distribuyó en los diferentes lugares que visitó -al menos se sabe de cinco de ellos en Lima, Potosí, La Plata (Sucre), Cuzco e Ica-. Su labor incluyó, también, una estrategia consciente por insertar dicha advocación entre las devociones patronales locales, para lo cual promovió la creación de cofradías dedicadas a la Guadalupe ${ }^{38}$.

Su labor de catequesis mariana comenzó en Lima. Aunque solo estaría algunos meses en la capital virreinal -conforme al plan de difusión continental que ambicionaba para su labor ${ }^{39}$-, el culto guadalupano prendió rápidamente en torno a la imagen que dejó en la ciudad, tanto que dos años más tarde se le erigió una capilla en las afueras de Lima ${ }^{40}$.

37 Agnès Gerhards, Dictionnaire historique des ordres religieux, París, Fayard, 1998, 296-297.

38 Kenneth Mills, "Ocaña, Diego de (ca.1570-1608)", en Joanne Pillsbury (ed.), Guide to Documentary Sources for Andean Studies, 1530-1900, Norman, University of Oklahoma Press, 2008, III, 457-464.

39 Según su propio relato: "Después que acabé de asentar por cofrades a toda la ciudad de Lima por el orden que dije, me pareció conveniente, pues había de andar toda la tierra firme, comenzar desde lo más apartado para después ir bajando y llegándome a España por el nuevo Reyno de Granada y venir a salir a Cartagena, a donde había comenzado, aunque después mudé de parecer, de ir por México por ser demas interés que no bajar por el Reyno como lo hice [...]. Y así me embarqué en el puerto del Callao en la nave [...] en la cual fue el socorro para la ciudad de la Concepción [...]": Diego de Ocaña, Viaje a Chile [fragmento del texto A través de la América del Sur], Santiago, Universitaria, 1995,31 .

40 Según el obispo Reginaldo de Lizárraga: "Es cosa admirable ver en cuán poco tiempo ha crecido la devoción a aquella iglesia; tiene un retrato al vivo de la imagen de Nuestra Señora de Guadalupe puesta en el altar mayor, que retrató el mismo religioso de San Hierónimo [...], con muchas piedras preciosas". Más adelante agrega: "Es mucha la frecuencia de la devoción de los fieles, porque cada día se dicen allí más de doce misas por devoción": Descripción del Perú, Tucumán, Río de la Plata y Chile, Madrid, Historia 16, 1986, 115-116; Rubén Vargas Ugarte, Historia del culto de María en Iberoamérica y de sus imágenes y santuarios más celebrados, Madrid, Talleres Gráficos Jura, 1956 ( $3^{\text {a }}$ ed.), I, 106-109. En Lima, en todo caso, existía otra cofradía, de similar advocación, pero establecida en la iglesia de San Agustín y vinculada a los negros y mulatos de la ciudad: Bernabé Cobo, Historia de la fundación de Lima [ca. 1636], en Obras, Madrid, Biblioteca de Autores Españoles, 1964, II, 455-456; Celestino y Meyers, Las cofradías..., op. cit., cuadro 14, 366. En 1653 vuelve a consignarse la presencia de esta cofradía: ibid., cuadro 20, 372 . 
A comienzos de 1600 se embarcaba rumbo a Chile, desde cuyo puerto nortino de Coquimbo comenzaría su deambular de cerca de tres meses, "[...] hasta llegar a lo último de la tierra de Chiloé; y en todos estos años no estuve de asiento en parte ninguna ni descansé [...] siempre caminando y comencé desde el principio de esta gobernación a asentar por cofrades de Nuestra Señora a todos, los cuales iban mandando sus limosnas [...]"41.

No obstante, el fraile llegaba en medio de la guerra hispanomapuche que se desató en 1598, debiendo escapar desde Osorno, a través de la cordillera, hacia Tucumán, encomendado por supuesto a Nuestra Señora de Guadalupe, "la cual siempre llevaba conmigo"42.

$\mathrm{Su}$ proyecto, por cierto, refleja la íntima relación que se daba en la época entre una imagen, su culto y la organización de corporaciones de devotos que se preocuparan de ella. Nos vemos tentados, por cierto, a vincular el rápido éxito que tuvo esta advocación en el espacio andino de esos años con la adscripción de sus inmigrantes al culto cofradial que se configuró desde comienzos del siglo XVII en Santiago; tentación que apela al papel que pueden cumplir las imágenes de devoción y su circulación geográfica, acompañando a individuos o grupos migrantes como soportes de protección sobrenatural, como referentes comunitarios y como "anclajes" de pertenencia a su espacio de origen y sus experiencias culturales ${ }^{43}$.

Si bien por el momento carecemos de indicios que nos confirmen dicha hipótesis, sí nos parece probable que la presencia de Ocaña y la energía puesta en su cruzada hayan estado a la base del establecimiento de la cofradía guadalupana en la capital chilena. Ello pues, aunque no sabemos con exactitud su fecha de instalación, sin duda debió de ser en esos años, si tenemos en cuenta que ya en 1610 se establecía el contrato por medio del cual la orden mercedaria cedía "la capilla que esta abaxo del coro de la dicha yglessia al entrar a mano derecha y se obliga de hazer el cuerpo y gueco della" dentro de los siguientes cuatro años, a cambio de lo cual "los dichos yndios" se comprometían a pagar 400 pesos "y poner todo el demas ornato nesçessario" 44 .

Ante el anhelado espacio que habían conseguido, los cofrades pusieron todo su empeño para cumplir este compromiso, quizás participando con sus conocimientos

41 Ocaña, op. cit., 45. Según Eugenio Pereira Salas, Ocaña no habría conseguido afincar en Chile el culto de la Virgen de Guadalupe. Otros cultos marianos más tradicionales se habrían desarrollado en forma más nítida en la zona de Concepción, donde el jerónimo estuvo la mayor parte del tiempo: ibid., 17.

42 Ibid., 46. Su recorrido lo llevó, luego, hasta Potosí, donde llegó en julio del mismo año. En Sucre fue acogido por el deán de Charcas, quien le facilitó las condiciones para que pudiese pintar la imagen que se conserva en la parroquia de San Juan de esa ciudad. Será la misma imagen -al parecer bastante sencilla y tosca en su composición- que irá reproduciendo en su paso posterior por Chucuito, Copacabana, Cuzco, Arequipa, Lima y Saña. Finalmente, en 1605 se embarca rumbo a México, donde muere tres años más tarde: ibid., 18-19.

43 Como apunta Pierre Ragon, muchas veces "no se sabe dónde se termina el éxito de la imagen cristiana y dónde comienza el del referente comunitario": Les saints et les images du Mexique, $X V I^{e}$ XVIII ${ }^{e}$ siècles, París, L’Harmattan, 2003, 344 (traducción nuestra).

44 Concierto entre el Convento de la Merced de Santiago y la Cofradía de Nuestra Señora de Guadalupe para la cesión de una capilla al interior de la iglesia (Santiago, 21 mayo 1610), Archivo Nacional Histórico, fondo "Escribanos de Santiago" (en adelante, ANH.ES), vol. 45, fjs. 209-210. 
artesanales en la construcción o haciendo donaciones en dinero que, eventualmente, podrían asegurar un lugar mortuorio destacado en la futura capilla. Así, por ejemplo, vemos al albañil Rodrigo, hijo de cuzqueño, que en su testamento de 1612 dejaba ocho pesos "para la obra de la capilla de la dicha cofradía donde soy hermano"45. Al año siguiente, el próspero albañil Gaspar, originario de Jauja, declaraba en quechua que era su cofrade, trasladando su deseo de sepultura desde Santo Domingo a la iglesia de la Merced y dejando quince patacones en su testamento para "la dicha cofradía de cuscos" 46 . Tan exitosa fue la actividad desplegada por los cofrades que, como vemos, ya desde 1613 podían sepultarse en su capilla, según se apunta en el testamento que dictó en ese año el sastre "cuzco" Diego, así como en los documentos posteriores del "cuzco" Alonso, en 1618, y de la india santiaguina Isabel de Agurto, en $1636^{47}$. Vemos, así, como los inmigrantes andinos se encuentran desde el primer momento en la configuración de la corporación. De hecho, la primera mención que se tiene de sus cofrades aparece en el testamento del huamanguino Diego Guamán, en 1610, donde además designa como albacea "a Alonso yndio procurador de la dicha cofradia" 48 .

Por cierto, en el mismo sector del templo donde se ubicaba la capilla de la cofradía - "arrimado al pilar del coro", como apuntaría su viuda al testar en 1643la orden vendió una sepultura al sastre limeño Sebastián de Iturrieta que, si bien mestizo, tenía una madre cuzqueña y él mismo declaraba abiertamente dicho origen. A lo largo de su vida conocida -desplegada desde que llegó a Santiago, a comienzos de la década de 1580 , y durante la primera década del siglo siguientemostró una constante relación con indígenas provenientes de los Andes, a quienes asentaba como aprendices o contrataba como oficiales, en caso de necesitar artesanos de calidad que apoyaran su prominente carrera ${ }^{49}$. Esta lo llevó a convertir su taller en uno de los más cotizados de la capital chilena e incluso a contarse dentro

45 Testamento de Rodrigo (Santiago, 5 febrero 1612), en Retamal, Testamentos.., op. cit., 136.

46 Testamento de Gaspar, "indio natural de Jauja" (La Chimba, 3 septiembre 1613), ANH.ES, vol. 81, fjs. 309v-310. No obstante, por razones que desconocemos, tres años más tarde dictaba otro testamento donde deshacía estas disposiciones y devolvía su lugar de entierro a la iglesia de los dominicos: Testamento de Gaspar (La Chimba, 23 noviembre 1616), ANH.ES, vol. 80, fjs. 190-191v.

47 Testamentos de Diego (Santiago, 6 mayo 1613), codicilio de Alonso (Santiago, 14 mayo 1618) y testamento de Isabel de Agurto (Santiago, 24 enero 1636), en Retamal, Testamentos.., op. cit., 143, 157 y 178. El primero quizás fuese Diego de Castro, indio "cuzco" nacido en Santiago, quien en 1591 se había asentado con su hermano Hernando, a la sazón oficial de sastre, con quien "ha comenzado a aprender el oficio de sastre [...] y querría acabar de aprenderle para con ello sustentar su persona, mujer y una madre que tiene". Hernando, por su parte, sabía firmar con su nombre y poseía -arrendaba- una pequeña tienda en la ciudad: ANH.ES, vol. 7, fjs. 305v-306. Este documento lo analiza y transcribe Emma de Ramón, "La incorporación de las etnias no hispanas a la actividad industrial durante la colonia temprana", Revista Archivo Nacional 2, Santiago, 2004, 42-47.

48 Testamento de Diego Guamán (Santiago, 12 octubre 1610), en Retamal, Testamentos.., op. cit., 133-134.

49 Iturrieta fue testigo, por ejemplo, en el testamento de Catalina, hija de indios "cuzcos", en 1591 (ANH.ES, vol. 6, fjs. 251-251v); recibió como aprendiz al muchacho mestizo Alonso Lucas, en 1602 (ANH.ES, vol. 35, fjs. 267-267v); pagó lo adeudado por el indígena andino Alonso -en base a una denuncia por hurto hecha en su contra por otro cuzqueño- y lo asentó como su aprendiz de sastre, en 1607 (ANH.ES, vol. 36, fjs. 34-34v); asentó como aprendiz de sastre a Diego "indio del Cusco" -obligándose a "enseñarle a su saber y entender"- en 1609 (ANH.ES, vol. 39, fj. 306v). 
del grupo de selectos maestros de sastrería que en 1614 fundaron otra cofradía dedicada a la virgen en la Catedral ${ }^{50}$. Llama la atención, por otra parte, que Iturrieta adquiriera aquel espacio del templo mercedario no solo para ser sepultado, sino también como lugar reservado a su "linaje" -es decir, a sus descendientes-, para que se ubicara en forma exclusiva y privilegiada durante los servicios religiosos; una muestra de extrema afección de los mercedarios por un artesano mestizo, pues era distinguido, así, de la cofradía de los Nazarenos, situada en la misma iglesia y a la que pertenecía buena parte de sus colegas ${ }^{51}$.

Hemos visto, pues, que la Guadalupe concentraba un importante número de aquellos indios inmigrantes llamados cuzcos. Esta denominación respondía a una suerte de "etnónimo" que, usado indistintamente por el sistema colonial -autoridades, escribanos, Iglesia, etc.- o por los mismos aludidos, refería a una identidad -o, más bien, una autoidentificación- que reivindicaba una situación privilegiada de los andinos y heredada, cuales "beneméritos indígenas", por sus descendientes. Esta situación derivaba del apoyo que estos o sus ascendientes brindaron a los conquistadores españoles y les permitía diferenciarse de los otros indígenas locales y foráneos que habitaban la ciudad y sus alrededores. Se trataba, por cierto, de una denominación que no era propiamente étnica, sino más bien histórico-geográfica, en la medida en que apelaba a una coyuntura temporal específica y englobaba a individuos de orígenes regionales diferentes pero vinculados geográficamente al espacio andino y a su legendaria capital inca $^{52}$.

Por todas estas razones, los cargos internos de la Guadalupe, "nombrada de la adbocaçion de los yndios naturales y desendientes de cuzcos", quedaron generalmente en manos de aquellos inmigrantes, al menos durante sus primeros años de funcionamiento $^{53}$. De hecho, en 1615 sus mayordomos y procuradores daban poder al provincial mercedario que partía a Europa, para que pidiese la confirmación de su fundación. El poder fue rubricado, en nombre de todos los demás, por el mayordomo cuzco Diego Quispe, ya que era el único que sabía firmar. Los cofrades también encargaron al fraile que solicitara la concesión de privilegios a los que supuestamente tendrían derecho estos andinos y sus descendientes por el papel jugado en la conquista:

50 Carta de constitución de la cofradía de los sastres en la catedral de Santiago (Santiago, 3 junio 1614), ANH.ES, vol. 52, fjs. 73v-76. Interesa destacar que, pese a este manifiesto ascenso sociolaboral que caracterizó su vida, Iturrieta fue uno de los dos sastres - de los nueve fundadores- que no supo firmar.

51 Emma de Ramón, “Juan Chico de Peñalosa, Sebastián de Iturrieta y Martín García, tres sastres en los albores de la industria santiaguina: 1560-1620", en Julio Retamal Ávila (ed.), Estudios coloniales III, Santiago, Universidad Andrés Bello, 2004, 100-103.

52 Véase nuestro trabajo "Inmigrantes en busca de identidad: los indios cuzcos de Santiago de Chile, entre clasificación colonial y estrategia social", en Alejandra Araya y Jaime Valenzuela (eds.), Denominaciones, clasificaciones e identidades en América colonial, Santiago, Pontificia Universidad Católica de Chile, Instituto de Historia, Universidad de Chile, Facultad de Filosofía y Humanidades, RIL, 2010. Una perspectiva similar fue planteada por Carlos Ruiz Rodríguez, "El mestizaje en Chile. Aspectos ideológicos", en Historia de las mentalidades. Homenaje a Georges Duby, Santiago, Universidad de Chile, 2000, 248.

53 Ruiz, "Cofradías...", op . cit., 26; ANH.ES, vol. 53, fjs. 191-191v. 
“[...] y asymismo para que ante su magestad en Rey don phelipe nuestro señor y su rreal consejo pidan se nos agan merçedes y los prebilexios que ffuere seruido atendiendo que somos sus leales basallos naturales del piru y hijos los mas de los hermanos de la dicha coffradia de padres cuzcos y de los que entraron a la conquista deste Reino y le sirbieron en el como es notorio y en espeçial pida sseamos puestos en los actos puvlicos con las ynsignias de la dicha nuestra coffradia en lugares honrrosos Prefiriendo a los negros y mulatos que nos lo an pretendido ympedir y tambien a los naturales desta tierra pues no an sido tan fieles como nosottros" 54 .

Debemos insistir respecto de la diversidad étnica y geográfica que se ocultaba tras esta "identidad" cuzco, toda vez que, como lo revela el cuadro $\mathrm{N}^{\circ} 1$, los testantes guadalupanos provenían de lugares tan distintos como Huamanga (Ayacucho), Quispicanchis (Cuzco) o Jauja (Junín).

Esta diversidad se amplía si tomamos en cuenta la incorporación de indígenas “chilenos" -atestiguada al menos desde 1619-, quienes, a su vez, también provenían de lugares y culturas diferentes, como el valdiviano Miguel, la ya citada santiaguina Isabel de Agurto o la cofrade María de Ahumada que, siendo natural de Córdoba, en Tucumán, era esposa del potosino Pedro Durán. Por cierto, allí estaba Luisa de Araya, que al momento de testar estaba casada con el cuzco Francisco de Cháves (véase el cuadro $\mathrm{N}^{\circ} 3$ ).

Los morenos tampoco estuvieron ausentes de esta corporación que, pese a la avasalladora presencia andina en sus cargos y denominaciones, daba señales de su contenido pluriétnico a través de algunos fragmentos documentales. Así lo revela la declaración de un mulato llamado Jerónimo Alberto, condenado a la horca en 1610. En el mismo año en que se firmaba el compromiso para la habilitación de la capilla cofradial, este artesano sillero dejaba los cincuenta pesos que tenía para el convento de la Merced, treinta de los cuales debían pasar directamente a dicha cofradía ${ }^{55}$.

La escasez de documentación específica nos impide estudiar en forma sistemática la evolución que pudo tener esta institución a lo largo del siglo XVII. No obstante, alguna información fragmentaria da indicios sobre los cambios producidos en su composición desde mediados de la centuria e, incluso, una cierta crisis en su identidad devocional hacia fines del siglo. En efecto, si tomamos en cuenta el total de testadores indígenas del período -tanto cuzcos como "chilenos"-, observamos que hasta 1646 aparece citada con cierta frecuencia e incluso en un documento del año anterior se mencionaba como uno de sus mayordomos a un tal Juan Puma, cuyo patronímico revelaría un origen andino ${ }^{56}$. Sin embargo, en las dos décadas que le siguen no aparece ningún indígena que mencione su pertenencia a esta corporación. En 1668 vuelve a reaparecer un cofrade andino que la

54 Poder de los mayordomos y de los procuradores de la cofradía de Nuestra Señora de Guadalupe a fray Juan de la Barrera, provincial de la orden de Nuestra Señora de la Merced (Santiago, 11 abril 1615), ANH.ES, vol. 53, fjs. 191-191v.

55 De Ramón, "Artífices negros...", op. cit., 64.

56 Testamento de Luisa de Araya (Santiago, 11 diciembre 1645), en Retamal, Testamentos..., op. cit., 183. 
declara en su testamento, para desaparecer definitivamente a continuación, al menos en este tipo de registro.

Por otra parte, en lo que dice relación con la identidad devocional de la cofradía, hacia fines del mismo siglo se percibe un cambio detectable a través de los inventarios de la iglesia de la Merced. Así, mientras en los registros de 1676 y 1683 encontramos en su capilla dos imágenes de bulto que representan, respectivamente, a la Virgen de Guadalupe y a Cristo resucitado, cuatro años más tarde, en un inventario de 1687, desaparece abruptamente la guadalupana, siendo reemplazada por Nuestra Señora de las Nieves ${ }^{57}$. Valga decir que en la Merced ya existía una cofradía bajo esta advocación, mencionada por primera vez en 1645, y cuya relación con los inmigrantes andinos había quedado confirmada en el testamento dictado en 1657 por el zapatero quiteño Andrés Machado, que a la fecha ejercía, paralelamente, como mayordomo de esta cofradía y de la de Nuestra Señora de Copacabana, en San Francisco ${ }^{58}$.

Pues bien, siguiendo el inventario de 1687 -y a falta de otros antecedentespodemos inferir que, o bien ambas corporaciones se fundieron -siendo fagocitada la guadalupana-, o bien esta última simplemente había perdido su fuerza devocional, siendo reemplazada por otra advocación más activa. En todo caso, fuesen estos u otros los motivos, lo cierto es que ahora la Virgen de las Nieves aparecía en un lugar central, presidiendo la capilla que había sido de la Guadalupe, y escoltada por otras imágenes mariales antes desconocidas: "Pasada la puerta el altar de Nra. Señora de las Nieves con el bulto de nuestra señora y un pequeño santo Cristo en la columna, que todo este altar es de la cofradía de los cuscos, con más dos bultos, el uno de la venerable María de Socos y el otro de María de la Antigua"59.

Otra documentación de esos años confirmaba el radical giro, pues en un registro general de las cofradías vigentes en Santiago en 1690 ya no se menciona a la de Guadalupe entre las vinculadas a la Merced, sino derechamente a la de Nuestra Señora de las Nieves. Además, ya no figuraba como mayordomo un indio andino, sino un mestizo, Cristóbal de Cháves ${ }^{60}$. ¿Sería, acaso, hijo de aquel cuzco casado con la cofrade Luisa de Araya, que testó en 1645? El estado de la investigación no permite afirmarlo, pero sí está claro que para fines de siglo habían cambiado tanto la orientación votiva como la composición étnica de la cofradía, "diluyéndose" el componente andino. También podemos argüir que dicha evolución podría estar en relación directa con el cambio del escenario demográfico de la propia ciudad, considerando que la parte sustantiva de la inmigración andina que había alimentado a esta y a las otras cofradías que veremos a continuación se había desarrollado durante la segunda mitad del siglo XVI y primeras décadas del siguiente. Hacia fines del siglo XVII, entonces, podemos inferir que la mayoría de estos "foráneos"

57 Archivo de la Provincia Mercedaria de Chile (en adelante, APMCh), "Libro de visitas (16761702)", fjs. 5-5v, 51v-52 y 65v, respectivamente.

58 Testamento de Andrés Machado (Santiago, 15 abril 1657), en Retamal, Testamentos..., op. cit., 194-197; Ruiz, "Cofradías...”, op . cit., 39, n. 72.

59 APMCh, "Libro de visitas (1676-1702)", fj. 65v (inventario de 1687).

60 Ruiz, "Cofradías...", op. cit., 38-39. 
había fallecido y que, quizás, sus descendientes, sobre todo a partir de la segunda generación, podrían haber tenido otras inclinaciones votivas o asociativas.

Esta tendencia queda reflejada en el inventario mercedario de 1701, donde la cofradía ya no solo es denominada oficialmente como "Nuestra Señora de las Nieves" -desplazando definitivamente a la advocación originaria-, sino que también desaparece la denominación "de los cuzcos" con la que aparecía tradicionalmente asociada, y que tampoco vuelve a mencionarse en los inventarios posteriores ${ }^{61}$.

El corolario de esta evolución podría marcarse a fines de ese mismo siglo, a través de un documento de 1797 donde se menciona como mayordomo a un mulato, el sastre Ambrosio Guerrero, quien también ejercía el mismo cargo en la cofradía de Nuestra Señora de Belén -además de ser "alféres de Artilleros de la Compañía Urbana de Milicias" de Santiago- ${ }^{62}$.

\section{NuESTRA SEÑora DE CopacABANA}

Bastante menos demandada que la anterior, en cuanto a la cantidad de inmigrantes andinos inscritos, se encuentra la de Copacabana, establecida en la iglesia de San Francisco desde antes de 1608, y que correspondía, en su origen andino, a una variante de la Virgen de la Candelaria, surgida hacia 1582 en las riberas altoperuanas del Titicaca (región del Collao) ${ }^{63}$.

61 El inventario de 1701 señalaba: "El altar de Nuestra Señora de las Nieves tiene su retablo dorado, un bulto de Cristo resucitado [-la única imagen que conservaba desde los primeros inventarios-], otro de santa María de Socos con sus velos y algunos lienzos de dicha cofradía": APMCh, "Libro de visitas (1676-1702)", fj. 142v. Se han revisado también varios inventarios redactados entre 1714 y 1766: APMCh, "Libro de visitas, Convento Grande: 1714-1843".

62 Archivo Nacional Histórico, fondo "Capitanía General", vol. 140, fj. 397v (agradecemos a Verónica Undurraga por esta referencia). Este documento es analizado, para un contexto diferente, en su artículo "Honores transversales, honores polisémicos en la sociedad chilena del siglo XVIII", en Alejandra Araya Espinoza et al. (eds.), Del nuevo al viejo mundo: mentalidades y representaciones desde América, Santiago, Universidad de Chile, Facultad de Filosofía y Humanidades, 2008, 65.

63 Su devoción se habría originado en el pueblo homónimo de la zona de Chucuito (Alto Perú), a partir de una imagen de la Candelaria tallada por un indígena local, la que habría sufrido una transformación milagrosa; situación que ocurrió, además, en un lugar dedicado antiguamente a una deidad femenina inca, a quien vendrá a reemplazar la Virgen. Se reproducía, de esta manera, la secuencia clásica por medio de la cual una entidad cristiana se imponía exitosamente sobre la idolatría. Por ende, según Estenssoro, fue una devoción que se insertó rápidamente en un plano alternativo a la nueva lógica tridentina instaurada por el III Concilio limense, toda vez que la asociación de la imagen y el milagro permitían establecer vínculos más directos e individuales entre los indígenas y la divinidad, a través del surgimiento de esta imagen-reliquia que materializaba la presencia de lo sobrenatural cristiano: Estenssoro, Del paganismo..., op. cit., 453; véase, también, nuestro trabajo ““...que las ymagenes son los ydolos de los christianos'. Imágenes y reliquias en la cristianización del Perú (15691649)", Jahrbuch für Geschichte Lateinamerikas 43, Köln, 2006, 41-65. La fama milagrosa de la imagen creció rápidamente, de la mano de los agustinos, llegando al Cuzco y a Lima a fines de la década de 1580. En ambas ciudades se crearon sendas cofradías de indígenas, siendo las del Cuzco más fragmentadas en función de la complejidad de las diferentes parroquias y barrios de la ciudad y marcadas por un contacto frecuente con el santuario del Collao a través de la migración, el comercio y el peregrinaje. En Lima, en cambio, se estructuró una sola gran cofradía, originada a partir de la copia de la imagen altoperuana que fabricó un indígena del barrio de San Lázaro, en la orilla extraurbana del río Rímac -el barrio indígena por excelencia de la capital virreinal-, imagen que luego sería traslada- 
Según la documentación consultada, esta sería, más bien, la cofradía preferida por los indígenas locales, característica que aparece explícita en un documento de 1613 donde se señala que esta corporación -cuyo mayordomo era "baltasar de san ffrançisco yndio"- había sido fundada en Santiago "por los naturales della y sus términos" $"$. Algunos años más tarde, en 1616, vuelve a señalarse esta característica en otro documento, donde Gaspar y Sancho, sus indios mayordomos, la señalan como "cofradía de los indios naturales de esta ciudad"65. Es interesante subrayar, en todo caso, que esta aparente unidad étnico-geográfica que imperaba en la cofradía -al ser de "indios naturales de esta ciudad"- era surcada por otros referentes identitarios que la diversificaban; específicamente, el referente laboral, pues, al parecer, muchos de aquellos "indios" eran artesanos y se dedicaban a especialidades distintas. Por mencionar un ejemplo, tenemos el caso del "hermano" Juan, "yndio ladino sastre", que en 1611 recibía cien pesos prestados por la cofradía, gracias al apoyo de otro indio, Miguel, "sapatero diputado" 66.

da, junto con los habitantes del barrio, a la zona del Cercado, que funcionaba desde 1571, cuando las reformas toledanas dispusieron concentrar allí a la población indígena de la ciudad; y fue en este barrio donde creció su fama milagrosa y su ligazón definitiva con el mundo indígena. Dicha fama, por su parte, hizo que aumentaran los medios económicos de la cofradía, que en los últimos años del siglo XVI llegó a contar con más de 2.600 cofrades, muchos de ellos indios ladinos y ricos que le legaron un patrimonio importante en bienes muebles e inmuebles. Este patrimonio permitió a sus dirigentes la decisión de construir su propia iglesia en el barrio de San Lázaro, donde finalmente regresaría la imagen en 1633. Gabriela Ramos ha destacado el hecho de que los testamentos revisados entre fines del siglo XVI y 1670 muestran que la filiación de indígenas cofrades era independiente de sus orígenes regionales, étnicos o de estrato social. Más aún, no solo indios, sino también mulatos, españoles y negros, de ambos sexos y diferente condición social, acudían a venerar la imagen con cierta regularidad. En este plano, justamente, Ramos busca develar la aparente exclusividad indígena de su culto, mostrando que fue una advocación transversal que convocó a personas de distintas procedencias sociales y étnicas -demostrada en la ubicuidad de sus imágenes en el ámbito privado-, lo que la situaría en un rol de mediadora cultural; papel que sería congruente con la inestabilidad y ambigüedades de la propia situación colonial: "Nuestra Señora de Copacabana ¿Devoción india o intermediaria cultural?", en Scarlett O'Phelan Godoy y Carmen Salazar-Soler (eds.), Passeurs, mediadores culturales y agentes de la primera globalización en el Mundo Ibérico, siglos XVI-XIX, Lima, Pontificia Universidad Católica del Perú, Instituto Riva-Agüero, IFEA, 2005, 163-165 y 170; Estenssoro, Del paganismo..., op. cit., 456-458; Vega Jácome, op. cit., 738-739. Cf., también, Alonso Ramos Gavilán, Historia del santuario de Nuestra Señora de Copacabana [1621], Lima, Ignacio Prado Pastor, 1988; Lizárraga, op. cit., 120-121; Cobo, op. cit., II, 454; Sabine MacCormack, "From the Sun of the Incas to the Virgin of Copacabana", Representations 8, Berkeley (CA), 1984, 30-60; Amalia Castelli, "Copacabana: un ejemplo de simbolismo religioso en el Altiplano", Histórica XIV:2, Lima, 1990, 355365; Vargas Ugarte, Historia del culto..., op. cit., I, 56-57 y II, 183-186; Lévano, "El mundo imaginado...", op. cit., 122; Mansilla, op. cit.; Celestino, "El trasplante...", op. cit., 108.

64 Carta de censo de cien pesos de plata a Pedro Mancera y Mariana de Vargas otorgados por la Cofradía de Nuestra Señora de Copacabana (Santiago, 9 enero 1613), ANH.ES, vol. 51, fjs. 19-20v.

65 Solicitud de sebo y pabilo para las procesiones (Santiago, marzo de 1616), Archivo del Arzobispado de Santiago (en adelante, AAS), "Secretaría", vol. 61, fjs. 272-275.

66 Carta de reconocimiento de deuda (Santiago, 14 marzo 1611), ANH.ES, vol. 41, fj. 60v. El adjetivo ladino hacía referencia, en términos específicos, a indígenas o negros que sabían hablar la lengua castellana y que podían servir de mediadores interétnicos. En términos amplios, implicaba también que estos sujetos conocían las formas culturales hispanocoloniales y podían aplicarlas como parte de sus estrategias de inserción y movilidad dentro de la sociedad, frente al sistema administrativo y ante las estructuras laborales: cf. Rolena Adorno, "El indio ladino en el Perú colonial", en Miguel León Portilla et al. (eds.), De palabra y obra en el Nuevo Mundo, México, Siglo XXI, 1992, I, 369-395. 
La cita anterior refleja, también, la solvencia económica de la corporación, que no hemos encontrado en las otras cofradías de indígenas estudiadas para la época y que probablemente se derivaba de la preeminencia de artesanos comprometidos con el sustento de su organización devocional. Dicha solvencia y disponibilidad de excedentes explicarían el hecho de que por esos mismos años en que se prestaban cien pesos al hermano Juan, otra cifra similar se entregaba a censo al zapatero español Pedro Mancera y su esposa, quienes, al parecer, no eran cofrades ${ }^{67}$.

Por otra parte, la "unidad" cofradial de los indígenas de Copacabana solo implicaba una máscara nominal que ocultaba la gran diversidad geográfica y cultural que se escondía detrás del mundo indígena urbano, considerando, como hemos visto, que una buena parte de ellos -si no la mayoría- también era inmigrante.

Así, podemos apreciar en el cuadro $\mathrm{N}^{0} 3$, por ejemplo, que entre los cofrades de Copacabana que testan a lo largo de este siglo no solo hay personas originarias de la capital, sino también del valle central (Rapel), de la Araucanía (Villarrica) e incluso de la lejana isla de Chiloé. Sin ir más lejos, la primera información que encontramos de esta cofradía aparece en el testamento de un indio originario del Tucumán, en 160868; mientras que, medio siglo más tarde, su mayordomo era el zapatero quiteño Andrés Machado, el mismo que ejercía paralelamente esa función, como vimos, en la cofradía mercedaria de la Virgen de las Nieves ${ }^{69}$.

La Copacabana no solo cumplía a cabalidad el papel que hemos asignado a las cofradías como canales de integración socioétnica, sino también como espacios de expresión barroca y seguimiento tridentino de las prácticas piadosas católicas de sus integrantes. En efecto, el documento de 1616 que citamos antes subrayaba su carácter penitencial, al denominarla, al mismo tiempo, como "cofradía de la sangre de los naturales". De hecho, el texto mismo es una solicitud elevada por los mayordomos al protector de indios para que este autorice el dinero necesario para costear las velas que iluminarían la participación de la corporación en la procesión nocturna del Jueves Santo ${ }^{70}$. Por su parte, Alonso de Ovalle también recogió esta orientación en su crónica, agregando que "es la más numerosa de disciplinantes, de todas las demás" 71 .

A fines del mismo siglo seguimos encontrando la denominación de "cofradía de indios", al igual que la subvención para Semana Santa -proveniente de la caja de censos de indios- y el carácter penitencial de su participación en ella. En este sentido, el dinero ya no aparece destinado solo a velas, sino también para "dar a los penitentes alguna conserva y biscochuelos y asi mismo un par de manos de

67 Carta de censo de cien pesos de plata a Pedro Mancera y Mariana de Vargas..., op. cit. Mancera era un artesano respetado entre los artífices de la capital: cf. ANH.ES, vol. 152, fjs. 400 y ss. (agradezco a Emma de Ramón por esta referencia).

68 Testamento de Alonso Rodríguez (La Chimba, 26 agosto 1608), ANH.ES, vol. 45, fjs. 494$494 v$.

69 Retamal, Testamentos..., op. cit., 194-197; Ruiz, “Cofradías...”, op. cit., 39.

70 Solicitud de sebo y pabilo..., op. cit., fjs. 272-275. En un documento del año anterior (1615), el procurador de la cofradía, Pedro de Uriona, solicitaba estos mismos insumos para la procesión de Jueves Santo: Archivo Nacional Histórico, fondo "Varios", vol. 270, pza. 8.

71 Ovalle, Histórica relación..., op. cit., 187. 
papel para curar a los que se azotan y les dan también tabaco y en la curación se hechase el lavatorio"72.

No obstante, en forma similar a lo sucedido con la cofradía guadalupana, la exclusividad indígena de su composición original se fue ampliando progresivamente hacia el universo mestizo e incluso español, llegando a asentar a connotados miembros de la élite local. En 1681, de hecho, su hermano mayor era Pablo de Villela, un comerciante español nacido en Vizcaya ${ }^{73}$. Por esos mismos años también participaba como cofrade Catalina de Irarrázaval y Andía, nieta de Francisco Bravo de Saravia, uno de los encomenderos más ricos de Chile ${ }^{74}$.

A lo anterior debemos agregar el gran cambio que se produce a fines de la década de 1680, a partir de la crisis de las cofradías dependientes de los jesuitas de Santiago, y que coincide, sintomáticamente, con la transformación experimentada por esas fechas en la guadalupana de la Merced. En efecto, promediando el decenio, la Compañía de Jesús entró en franco conflicto con las cofradías de indios (del Niño Jesús) y de negros (de Belén), fundadas en su colegio capitalino; conflicto derivado, al parecer, de la nueva actitud jesuita que buscaba fortalecer la ortodoxia de estos cofrades por la vía de la extirpación de sus formas devocionales y festivas más "paganas"75. Frente a la virtual negativa de los cofrades, la orden decidió expulsarlos de su iglesia, junto con sus imágenes, adornos y todas sus pertenencias. Esta decisión quedó estipulada canónicamente en el propio sínodo diocesano que se celebró en Santiago en 1688, el que, justamente, contó con una destacada participación de varios jesuitas. Allí se estipulaba que la cofradía de indígenas debía "agregarse" a la de Copacabana o disolverse definitivamente ${ }^{76}$.

No disponemos de más antecedentes sobre el desenlace de esta coyuntura, pero podemos suponer que la llegada de este nuevo contingente y de sus objetos devocio-

72 Expediente del protector Recalde y Briceño sobre pedir limosnas para procesión (1681), AAS, "Provisor", sección "Asuntos diversos", expediente 480, fj. 2. El último libramiento de dinero que se recoge en este documento data de 1706.

73 Ruiz, "Cofradías...", op. cit., 30-31.

74 Así lo declaraba en el testamento redactado poco antes de su muerte, en 1694: Hernán Rodríguez Villegas, "Historia de un solar de la ciudad de Santiago, 1554-1909", Historia 11, Santiago, 1972-1973, 119. No obstante, Catalina no fue enterrada junto con los de su cofradía, sino que en otra iglesia y en un espacio más exclusivo: la sepultura familiar que se ubicaba en el presbiterio de la capilla mayor de la Merced, del lado del evangelio: idem.

75 Francisco Enrich, Historia de la Compañía de Jesús en Chile, Barcelona, Imprenta de Francisco Rosal, 1891, II, 8-9. Esta situación es tratada con detalle en Víctor Rondón, Jesuitas, música y cultura en el Chile colonial, Tesis de Doctorado en Historia, Pontificia Universidad Católica de Chile, Santiago, 2009, 378 y 382-384.

76 Sínodos diocesanos del Arzobispado de Santiago de Chile celebrados por los ilustrísimos señores doctor don fray Bernardo Carrasco Saavedra [1688] y doctor don Manuel de Alday y Aspee [1763], Nueva York, Eduardo Dunigan y Hermano, 1858: sínodo de 1688, cap. VII ("De las cofradías"), const. IV, 55. Llama la atención la elección de la Copacabana como la destinataria de estos cofrades expulsados de la Compañía, toda vez que en la década de 1630 se desató un conflicto de proporciones entre franciscanos y jesuitas por el orden de precedencia de sus respectivas cofradías indígenas en las procesiones públicas, "con que se alteraron nuestros cofrades de modo que si no nos opusiéramos, y con la fuerza de la verdad venciéramos los contrarios en juicio, corría detrimento nuestra congregación y cofradía, siendo de esta condición los indios de esta tierra": "Letras anuas de la V. Provincia de Chile del año de 1634 y 33", Archivum Romanum Societatis Iesu, "Chile", vol. 6, fj. 72. Esta información se confirma en la carta anua de 1635-1636, fj. 113v. 
nales debió ejercer una transformación importante en la corporación franciscana, reforzando, por un lado, su contenido "indígena" y la complejidad étnica que suponía la diversidad identitaria que se escondía tras dicha categoría colonial. Aunque documentación más tardía nos da indicios de que también se habría abierto al mundo de los morenos, como lo muestra el testamento dictado en 1762 por el "pardo libre" Juan Joseph Flores; si bien aquí podía estar actuando el criterio de integración laboral, toda vez que Flores era "maestro de zapatería"77. Por otro lado, esta fusión pudo implicar un refuerzo en la organización interna y en el peso relativo de la cofradía dentro del sistema corporativo-devocional de la capital, lo que se refleja en su participación religiosa en el espacio público aún a mediados del siglo XVIII ${ }^{78}$.

\section{Nuestra SEÑORA DE LA CANDELARIA}

Los andinos también integraron la cofradía de la Candelaria, establecida en el convento de San Agustín hacia $1600^{79}$. En su origen, por cierto, fue fundada por negros libres y concebida para ellos, pero rápidamente adquirió un contenido plural, al incorporar al mundo indígena de la ciudad. Así aparece indicado desde 1610 en sus constituciones -que serán finalmente aprobadas por el obispo en 1615-donde se la definía como una entidad integrada por "mulatos orros" y por "naturales oficiales", dando cuenta, con esto último, de la preeminencia otorgada al ingreso de indígenas que ejercieran como artesanos ${ }^{80}$. Incluso, el mismo documento deja en claro que los cargos internos de la cofradía debían repartirse en igualdad de condiciones y responsabilidades entre ambas "naciones", apareciendo los veinticuatro divididos equitativamente entre "morenos" y "naturales", cada grupo con su respectivo mayordomo y procurador ${ }^{81}$. Esta diferenciación "étnica" también se daba en el registro de género pues, al menos desde la aprobación de las constituciones, existieron "mayordomas" elegidas anualmente para "mulatas" y para "naturales" 82.

77 "Poder para testar de Juan Joseph Flores a Asencio Rojas y otros" (Santiago, 30 mayo 1762), ANH.ES, vol. 771, fjs. 124v-126.

78 Véanse, por ejemplo, los registros de gastos de la cofradía para el año 1752, en AAS, "Provisor", sección "Asuntos diversos", expediente 503. Es necesario consignar, en todo caso, que en la recopilación de testamentos indígenas publicados por Julio Retamal, la Copacabana aparece por última vez en 1696; y que en un registro de 1690 se menciona otra cofradía con el mismo nombre, además de la de San Francisco, establecida en el convento de San Agustín: Ruiz, "Cofradías...”, op. cit., 39.

79 Falch, "Cofradía...", op. cit., passim. Para el Perú, el desarrollo inicial de este culto en la zona de Arequipa está descrito en Alejandro Málaga Núñez-Zeballos, "La Virgen Candelaria en el obispado de Arequipa: origen y milagros", en Decoster (ed.), op . cit., 347-358.

80 Constituciones de la cofradía, transcritas en Falch, "Cofradía...", op. cit., $1^{\text {a }}$ parte, 26; Ruiz, "Cofradías...", op. cit., 30.

81 Falch, "Cofradía...", $1^{\text {a }}$ parte, 26 (const. n ${ }^{\text {2 }}$ ).

82 "Libro de la Cofradía de N ${ }^{a}$ Sra. de la Candelaria, en el Convento de San Agustín" (16061651), sin foliación para estas páginas. Es necesario destacar que, a diferencia de las otras cofradías analizadas en este artículo, donde solo encontramos información fragmentaria que nos obliga a conjeturar sobre la base de indicios, para la Candelaria de San Agustín contamos con este registro relativamente regular de sus elecciones entre 1612 y 1651 ; ello, pese a la ausencia de información para varios años, a la intermitencia de su foliación y a la transposición cronológica que muchas veces se observa entre registros diversos (elecciones, asentados, ingresos, defunciones, ...). El "Libro" incluye, tam- 
Por cierto, esta diversidad de la Candelaria también debió proyectarse al universo de sus expresiones religiosas, contribuyendo a hacer más ricas las prácticas volcadas al espacio público, tanto para su fiesta anual -el día la Purificacióndonde todos los integrantes debían participar con velas encendidas en sus manos, como, sobre todo, para la "procesión de sangre" que se desarrollaba los martes de Semana Santa. En esta, como apuntaba un cronista de las primeras décadas del siglo, los cofrades desfilaban "con sus túnicas negras y sacan muchos y muy devotos pasos de la pasión, acompañados con mucha cera, y la música es de las mejores del lugar" 83 .

El inventario de bienes que registra la cofradía para 1614 contemplaba una serie de imágenes, cruces, pendones, telas negras y más de cien "hacheros", destinados a iluminar los "pasos" de la pasión, que eran llevados a través de las calles santiaguinas sobre los hombros de los cofrades enlutados; objetos y soportes devocionales que consumían una parte no despreciable del presupuesto anual. Destacaban, además de la escultura misma de la Virgen, con el Niño Jesús en los brazos y una candela en la mano, otras tres imágenes de bulto utilizadas para esta fiesta anual y cuyo simbolismo penitencial marcaba la religiosidad barroca de la corporación. Se trataba de un Cristo con las manos atadas y una soga al cuello, otra del mismo orando en el huerto y un ángel con un cáliz y una cruz en sus manos ${ }^{84}$.

Ahora bien, con respecto a la participación de inmigrantes andinos, el libro que se conserva con las cuentas y registros de la cofradía para la primera mitad del siglo XVII nos permite ver cómo, en los veinte años que siguieron a su organización oficial desde la entrada en vigencia de las constituciones de 1615, estos indígenas jugaron un rol importante en el funcionamiento interno. Llama la atención, en este sentido, la aparición regular de algunos de ellos entre los elegidos para administrar la institución. En efecto, ya en septiembre de aquel año asumía como "mayordomo de naturales" el maestro sastre Juan de Luna, "yndio del cuzco", a quien dos años antes lo encontramos arrendando un solar en el sector de la Chimba $^{85}$. En 1615 también fue elegido, como alférez, el sedero y sombrerero

bién, algunas matrículas parciales de cofrades indígenas masculinos (una lista de los asentados antes de 1633 y los asientos nuevos y pagos anuales de 1633, 1637 y 1640) y femeninos (asientos nuevos y pagos anuales de $1620,1622,1630,1639,1640$ y 1643): fjs. 43-45 y 53-54v, respectivamente. El original de este documento se encuentra en AAS, desde el cual Jorge Falch transcribió y publicó algunos fragmentos, así como una lista alfabética de las distintas personas mencionadas en él: "Cofradía...", op. cit., $1^{\text {a }}$ y $2^{\text {a }}$ parte. Este texto es de gran utilidad, pero hemos preferido hacer una relectura de la fuente original, que no solo contiene material inédito, sino que también permite seguir y "sentir" linealmente (con sus desfases y tensiones) el desarrollo de esta corporación. Agradecemos la gentileza del conservador del Archivo Provincial de San Agustín, Guillermo Carrasco Notario, que nos facilitó la consulta de la copia fotostática que allí se conserva.

83 Ovalle, Histórica relación..., op . cit., 187.

84 "Libro de la Cofradía...", fjs. 187-188v; Falch, "Cofradía...", op. cit., 2ª parte, 177-178. En el testamento que dictaba en 1613 el sastre mulato Juan de Morales, cofrade de la Candelaria, dejaba cuatro pesos para el ornato de la imagen de la virgen: Kordic (ed.), "Testamentos coloniales chilenos, op. cit., 151-152.

85 Arriendo de un solar en la Chimba de Juanes de Herrera a Juan de Luna (Santiago, 9 julio 1613), ANH.ES, vol. 46, fj. 56. 
originario de Huánuco, Andrés Bañado Pongo ${ }^{86}$. En 1616, por su parte, aparece como procurador de la cofradía otro andino, Agustín Quispe. El año 1617 será en el cual Bañado se posicione como "mayordomo de naturales", cargo en el que será reelegido sucesivamente hasta comienzos de 1619. En este, por su parte, vemos aparecer a Francisco Cuzco como alférez, del cual no poseemos más datos, pero cuyo origen andino se hace evidente a través de su "patronímico". En la siguiente elección, llevada a cabo a comienzos de 1622, el cargo de alférez recaerá en otro andino, Diego Quispe, probablemente un pariente de quien había sido procurador en 1616. Por cierto, ya nos habíamos encontrado con Diego al tratar sobre la cofradía de Guadalupe, donde en 1615 ejercía como uno de sus mayordomos ${ }^{87}$. A comienzos de 1623 regresa Andrés Bañado como mayordomo, siendo reemplazado al año siguiente por el mencionado Diego Quispe, cuyo rápido ascenso mostraba sus dotes "políticas", sin duda auspiciadas por sus dotes "letradas"-recordemos que en el documento de la Guadalupe citado, Quispe había sido el único que sabía firmar- ${ }^{88}$. Bañado se mantuvo durante ese año de 1624 , en todo caso, dentro del grupo dirigente de Copacabana, asumiendo como su hermano mayor, pese a los problemas de salud que, pensamos, pudieron haberlo llevado a dictar su testamento ${ }^{89}$. De hecho, su presencia activa al interior de la corporación se confirma cuando, en 1626, vuelve a ser elegido como mayordomo. Junto a él aparece como alférez otro andino, Juan Cuzco. Al año siguiente, por su parte, vemos el regreso de Juan de Luna a la mayordomía de los naturales, turnándose el cargo con Bañado en las elecciones de 1628 (Bañado) y 1629 (Luna). Ambos cuzcos vuelven a repetir esta rotación en 1632 (Bañado) y 1633 (Luna).

86 Dos años antes Bañado se había asentado como sedero con Alonso Sarfate, que ejercía el mismo oficio: "Asiento de trabajo de Andrés Guañado natural de Guánuco" (Santiago, 19 junio 1613), ANH.ES, vol. 51, fj. 262.

87 Poder de los mayordomos y de los procuradores..., op. cit., loc. cit.

88 Resumiendo los datos que poseemos sobre este posicionamiento sociorreligioso de Quispe, debemos considerar su mayordomía en la Guadalupe de 1615 y su traslado a la Candelaria, que pudo haber estado influido por la presencia, en esta última, de su eventual pariente y procurador en 1616, Agustín Quispe. Es interesante constatar que en 1619 encontramos a un Diego Quispi "concertándose" para servir por un año al maestro sombrerero Melchor de los Reyes -cuyo "patronímico" podría ser un indicio de su origen limeño-. Durante ese tiempo, Quispi se ocuparía "en el oficio de cardador de lana para sombrero y en aforrallos que sabe y cayrelallos". La constatación de que Quispi "sabe" cardar y el monto asignado como salario anual -120 pesos y dos sombreros "finos aderesados", además de la comida diaria- estarían mostrando a una persona con conocimiento en el oficio -al menos en la fase preparatoria de la fabricación de los sombreros-. Pero, además, el contrato estipulaba que Diego se quedaría con tres libras de lana fina cardada por cada día de trabajo: "Asiento de trabajo de Diego Quispi, indio" (Santiago, 6 junio 1619), ANH.ES, vol. 85, fj. 249v. Esto último, pensamos, podría entenderse dentro de la lógica de aprendizaje especializado vinculado con la relación maestro-aprendiz característica de la época y recogida regularmente en los asientos de trabajo con los maestros de la ciudad. Quispi estaría, así, en medio de un proyecto personal para convertirse él mismo en un artesano del oficio. Conforme a esta hipótesis, entonces -y de ser la misma persona-, en la época en que lo vemos ejerciendo como mayordomo de la Candelaria (1622 y 1624), Diego no solo sabría escribir, sino también podría estar convertido en un próspero maestro sombrerero, lo que le habría dado el sustento social necesario para ocupar el principal cargo de la cofradía.

89 Testamento de Andrés Bañado Pongo (Santiago, 16 marzo 1624), ANH.ES, vol. 87, fjs. 132133v; una versión impresa -con errores de transcripción- en Retamal, Testamentos..., op. cit., 168170 
Dentro de esta dinámica, quisiéramos destacar el declive paralelo que al interior de la cofradía sufrió, al parecer, el estamento de los "morenos", pues desde comienzos de la década de 1630 escasean los cofrades elegibles para ocupar los cargos reservados a su "nación", situación que hace crisis en la elección de mayordomos de 1633, momento en que se determinó que, en adelante, fuese uno solo el mayordomo en funciones. Junto a él se elegiría un diputado "de diferente nación de la del mayordomo", al que le tocaría asumir en el período siguiente, en base a un sistema de turnos. Pues bien, realizada la votación de ese año por todos los cofrades, salió elegido, como hemos visto, el sastre andino Juan de Luna, pese a que el año anterior también había sido un andino, Andrés Bañado, el que había ejercido el cargo en el turno de los "pardos" 90 . Con ello se comprueba la influencia predominante de estos inmigrantes al interior de la Candelaria, incluso más allá del sector propiamente indígena de la institución, pues también votaron por él los "morenos".

El año 1637 será el último en que vemos aparecer a Luna como mayordomo y a Bañado como "alférez de naturales" -este último ocupando nuevamente el espacio que le correspondía a un "pardo", en vista de que continuaba la escasez de estos candidatos- ${ }^{91}$. Desde ese momento dejan de aparecer andinos en los cargos y tampoco se consignan entre los demás cofrades asentados en esos años -aunque la información sobre estos, como hemos indicado, es fragmentaria y solo cubre algunos años del período-.

Considerando lo anterior, parece pertinente, entonces, reanudar la pregunta sobre la "decadencia" en la presencia de andinos que hemos visto para otras cofradías desde mediados del siglo XVII, ausencia que parece más evidente en contraposición con la activa participación vista durante las décadas previas. Esta situación se conjuga con lo que también hemos visto en las otras corporaciones estudiadas, en el sentido de que en la Candelaria se observa una "hispanización" de su contenido con la llegada de mestizos e hispanocriollos que, ya desde la década de 1620, comenzaron a cambiar la orientación "biétnica" inicial. De hecho, en el testamento que dicta en 1619 el herrero mestizo Diego Mejía, originario de Quito, estipulaba que fuese enterrado en la iglesia de San Agustín, "en el lugar que se da sepultura a los hermanos de la cofradía de la candelaria donde mando me asienten por hermano" $" 92$. Ese mismo año testaba la cofrade Francisca Cardoso que, siendo mestiza, había ingresado a la Candelaria como "española"93. Entre los hispanocriollos llegamos a encontrar a uno de los más destacados miembros de la élite, Juan Rodulfo Lisperguer, con su esposa e hijos, asentados en 1633; y a Mariana Valverde, propietaria de un esclavo que también era cofrade de la misma corporación ${ }^{94}$. Incluso aparecen algunos portugueses en la segunda mitad del siglo ${ }^{95}$.

90 Auto y elección de mayordomo (23 de enero de 1633) y actas de elecciones de mayordomos y oficiales (1 de enero de 1632), "Libro de la Cofradía...", op. cit., fjs. 58-59 y 181, respectivamente.

91 Ibid., fj. 184.

92 Testamento de Diego Mejía (Santiago, febrero 1619), ANH.ES, vol. 59, fjs. 95-95v.

93 Ruiz, "Cofradías...", op. cit., 30.

94 "Libro de la Cofradía...", op . cit., fj. 9. En total, el libro consultado contempla unos treinta asientos de "españoles" hasta 1642, último año en que tenemos sus registros, de acuerdo a la fragmentación y suspensión de esta fuente según hemos detallado en la nota 82 .

95 Ruiz, "Cofradías...", op. cit., 31, n. 33. 
La creciente presencia de hispanos e hispanas los llevó incluso a buscar posicionarse como un núcleo en similares condiciones políticas con las otras "naciones", intención que se concretó en 1634 con las cofrades que eligieron a su "Hermana mayor de las españolas". Al año siguiente, no obstante, los estamentos tradicionales -"morenos" y "naturales"- reaccionarían, determinando que los españoles podían tener voto activo, pero no podían ser elegidos en los cargos cofradiales $^{96}$.

\section{JESÚS NAZARENO}

Una cuarta cofradía donde participan los indígenas andinos es la de Jesús Nazareno, fundada en el convento de la Merced a fines del siglo XVI o comienzos del XVII, y que fue la más numerosa a lo largo de la época colonial. Al igual que en la institución del mismo nombre establecida en el convento agustino de Lima, los nazarenos santiaguinos habrían sido fundados por españoles nacidos en Burgos ${ }^{97}$.

No obstante, según relata el jesuita Alonso de Ovalle, hacia mediados del siglo XVII ya no solo primaría un criterio étnico hispano en la conformación de la cofradía chilena, sino también el laboral, pues se incluían a "maestros y oficiales de varias artes"98; y, considerando la composición étnica que circulaba entre los artesanos locales, no sería extraño que entre estos cofrades hubiese un número significativo de mestizos e indígenas. De hecho, no solo burgaleses, sino también indígenas o mestizos andinos se encontraban entre sus fundadores, como el zapatero Hernando Muñoz, nacido en Huánuco e hijo natural de Hernán Muñoz, residente, a su vez, en Lima ${ }^{99}$. También encontramos el caso de la mestiza Antonia de la Cueva, que en su testamento de 1611, si bien pidió sepultura en San Agustín, dejó alhajas para la cofradía de los Nazarenos ${ }^{100}$; o la mestiza Ana de Salazar, nacida en La Serena, que en su testamento de 1627 declaraba poseer ropa de uso español e indígena, e incluso "unas taças en que veven los indios a husança del Cuzco"101. A fines de siglo, en 1690, volvemos a encontrar en un alto cargo de los nazarenos, esta vez como mayordomo, a otro mestizo, Francisco Constanzo ${ }^{102}$. Contamos tam-

96 Elecciones de mayordomos y oficiales, "Libro de la Cofradía...", op. cit., fjs. 181-184.

97 Celestino, "El trasplante...", op. cit., 105. En un registro de cofradías limeñas de 1619 aparece la cofradía del Santo Crucifijo de Burgos, formada por españoles y establecida en el convento de San Agustín: Celestino y Meyers, Las cofradías..., op. cit., cuadro 7, 358. La similitud del nombre y de la filiación burgalesa de la cofradía chilena hacen pensar que quizás estuviese asociada a aquella y que la imagen del Cristo de Burgos, instalada desde 1594 en la capilla de Juan de León, en el templo mercedario de Santiago, fuese una copia del Cristo limeño: cf. Isabel Cruz, Arte y sociedad en Chile, 1550-1650, Santiago, Universidad Católica de Chile, 1986, 228 y 245-246.

98 Ovalle, Histórica relación..., op. cit., 187. Quizás dentro de este registro se incluiría Guillermo Barbero, cuyo "patronímico" podría ligarse a un oficio, y que en el poder para testar que dictó en 1612 declaraba su intención de ser sepultado en la capilla de los Nazarenos: Kordic (ed.), Testamentos..., op. cit., 149.

99 Ruiz, "Cofradías...", op. cit., 37-38.

100 Ibid., 51.

101 Citado en ibid., 37.

102 Ibid., 38. 
bién con otros datos fragmentarios de la década de 1670 que nos informan de dos indígenas chilenas -de Santiago y de Concepción- que en sus respectivos testamentos mencionan su pertenencia a esta corporación ${ }^{103}$.

\section{EN BUSCA DE REFERENTES COMPARTIDOS: A MODO DE CONCLUSIÓN}

Como hemos visto en cada una de las cofradías estudiadas, estas se construyeron como espacios que integraban a personas con orígenes sociales, étnicos y geográficos muy distintos. Los indios andinos inmigrantes, que experimentaban entre ellos esa misma diversidad, pero que eran vistos por la sociedad chilena $-\mathrm{y}$ se presentaban a sí mismos- con una "identidad" común, basada justamente en la identificación con el espacio andino, llegaron a formar parte de esos canales corporativos de devoción, muchas veces en sus rangos fundacionales y dirigentes.

Las cofradías se instalaron, así, en medio de la complejidad étnica y de la multiplicidad de referentes identitarios de la población urbana, dando un nuevo sentido de pertenencia institucional, en este caso religiosa, a sus variados componentes. Bajo esta perspectiva, podemos verlas como un espacio de integración, pero en un contexto "despersonalizado", caracterizado por identidades étnicas fragmentadas, desarraigadas o amestizadas, propias de un contexto urbano colonial ${ }^{104}$.

En el caso de Santiago ayudaría, además, el hecho de que, a diferencia de lo que sucedía en otros lugares, prácticamente no existían cofradías vinculadas a gremios de artesanos específicos; situación debida, probablemente, a que no existían estos "gremios", en el sentido institucional del término. Los de Santiago serían más bien artesanos de tal o cual oficio, que se definían -o que eran definidos por la autoridad municipal- como miembros de un hipotético gremio, inevitable dentro de la concepción corporativa subyacente a la ideología social de la época ${ }^{105}$. Así, las cofradías santiaguinas también se erigían como canalizadoras de una devoción transversal en términos laborales, incorporando en su seno a artesanos de diversos

103 Poder para testar de Constanza de Aguilera (Santiago, 21 septiembre 1671) y testamento de Magdalena de Araya (Santiago, 1676), en Retamal, Testamentos..., op. cit., 212 y 214.

104 Véase nuestro trabajo "Une société dépersonnalisée?...”, op. cit.

105 La idea de estos "artesanos sin gremio", como una realidad generalizada en el universo de los oficios de la capital chilena, la hemos discutido con Emma de Ramón, que se encuentra preparando un libro sobre los artesanos de Santiago colonial. Es mencionada, también, en relación con la falta de regulación profesional y con una vinculación corporativa de los artesanos más bien a nivel religioso -a través de cofradías "gremiales"-, en Villalobos, op. cit., II, 129, y en el capítulo introductorio al libro de Sergio Grez Toso, De la "regeneración del pueblo" a la huelga general. Génesis y evolución histórica del movimiento popular en Chile (1810-1890), Santiago, DIBAM, Centro de Investigaciones Diego Barros Arana, 1997, 46-55; también lo esboza, al pasar, Jaime Eyzaguirre, "Notas para la crónica social de la colonia: el gremio de zapateros de la ciudad de Santiago", en Boletín del Seminario de Derecho Público 6, Santiago, 1965, 3-4; y, para otras ciudades del continente, Lyman Johnson, "Artesanos", en Hoberman y Socolow (comps.), Ciudades y sociedad..., op. cit., 263. Véase también Guillermo Seymour, Los gremios de artesanos en Chile colonial, Memoria de Pedagogía en Historia y Geografía, Pontificia Universidad Católica de Chile, Santiago, 1972; Violeta Aracena, Los artesanos de Chile, siglo XVI, Tesis de Licenciatura en Historia, Universidad de Santiago de Chile, Santiago, 1987. Sobre este punto, conviene señalar que hemos variado la opinión que sostuvimos en Las liturgias..., op. cit., 48-51. 
oficios y latitudes ${ }^{106}$. De hecho, cuando en 1614 aparece una primera cofradía de carácter "gremial", fundada por un grupo de sastres en la Catedral, su carta de constitución dejaba expresamente indicada la facultad "para recibir hermanos a la dicha cofradía aunque no sean sastres y con la limosna que entraren según nuestro acuerdo han de ser legítimamente recibidos"107.

Si vemos a las cofradías estudiadas como caleidoscopios socioétnicos -es decir, como un conjunto diverso y cambiante, que fragmenta a la vez que integra-, podríamos entonces confirmar su papel en el despliegue exitoso de un sistema como el hispano que, luego de producir dichos quiebres -fruto de los procesos demográficos, sociales, laborales, culturales y políticos que implicó la propia organización colonial, de carácter "refundacional"-, ahora "ofrecía" canales de integración simbólica y de pertenencia social que terminaban siendo funcionales a su legitimación colectiva ${ }^{108}$.

Sin embargo, desde un prisma que privilegie la construcción de redes y referentes comunes, en forma paralela a las instituciones ofrecidas por el sistema, hay algunos indicios que nos permiten descifrar ciertas tendencias en relación con algunas pautas relacionales entre, al menos, parte de sus miembros. Así, constatamos que entre los fundadores de la cofradía de los nazarenos - por citar el último caso que mencionamos-, al lado del zapatero andino Hernando Muñoz, se encontraba el sastre mestizo Juan Chico de Peñalosa. Eran cofrades durante esos primeros años, también, el herrero Mateo Naranjo, el cuchillero Manuel González Guimaraes, el espadero mulato y de origen portugués Pedro González y los carpinteros Juan Bernal y Juan de Lepe, entre otros artesanos ${ }^{109}$. Tenemos, entonces, un primer eje común entre todos ellos -ser artesanos-, bajo el cual subyacen las relaciones interétnicas definidas por el origen distinto de, al menos, Muñoz (probable mestizo, de Huánuco) y González (mulato, de Lisboa). Este último, por su parte, llegó a ser un próspero artesano, con tienda de hechura y reparación de espadas, donde - como era costumbre en una economía deficitaria de numerario- también recibía numerosos objetos transados o empeñados por otras personas. En la lista de deudores que incluyó en su testamento, volvemos a encontrar a sus cocofrades Muñoz, González Guimaraes y Chico, así como a varios otros artesanos locales, de diversas especialidades ${ }^{110}$.

106 Judith Mansilla destaca una situación similar en las cofradías indígenas de Lima, donde la mayordomía era ocupada frecuentemente por oficiales artesanos -generalmente sastres y zapateros, en una tendencia similar a lo que hemos observado para la capital chilena-. Mansilla identifica, así, al mayordomo Hernando Quispe, natural de la región de Huaylas, que había llegado a Lima siendo niño, había aprendido el oficio de sastre y había escalado social y económicamente hasta ser oficial, tener un esclavo y llegar a ser mayordomo de la cofradía: "Exteriorizando...", op. cit.; sobre este tema, véase también el trabajo de Miguel Jaramillo, "Migraciones y formación de mercados laborales: la fuerza de trabajo indígena de Lima a comienzos del siglo XVII", Economía XV:29/30, Lima, 1992, 49-75.

107 Carta de constitución de la cofradía de los sastres en la catedral de Santiago (Santiago, 3 junio 1614), ANH.ES, vol. 52, fj. 73v.

108 Cf. nuestro trabajo Las liturgias..., op. cit., passim.

109 Emma de Ramón, "Juan Chico de Peñalosa...", op. cit., 100; Poder para testar de Pedro González, espadero (Santiago, 27 febrero 1613), ANH.ES, vol. 51, fjs. 116-116v.

110 De Ramón, “Artífices...", op. cit., 74-79. 
Si continuamos explorando las vidas individuales de estos cofrades-artesanos, acercándonos a sus relaciones más personales o los espacios donde habitaban, observamos ciertas coincidencias que abren nuevas e interesantes perspectivas en el marco de las hipótesis planteadas en este trabajo. Si nos enfocamos sobre el caso de Juan Chico, por ejemplo, vemos que si bien este sastre era originario de Concepción, estuvo casado algún tiempo con Isabel de Gálvez, hija mestiza de una indígena originaria de Quito. Su vinculación con el mundo andino era tal, que conocía perfectamente la lengua quechua; tanto así que en una oportunidad concurrió como traductor a la casa de su vecino, el indio "cuzco" Gaspar Guanca, albañil, que no hablaba castellano y que deseaba dictar un nuevo testamento -con anterioridad había dictado, al menos, otros dos testamentos y un codicilio, según vemos en el cuadro $\mathrm{N}^{\circ} 1$-. Por cierto, el otro testigo del testamento de Guanca fue un hijo de Chico, que también entendía dicha lengua ${ }^{111}$.

Tenemos, así, a dos artesanos (sastre y albañil), que comparten una cercanía cultural con el espacio andino (lengua, familia, etc.), pero que, además, viven en un mismo sector de la ciudad: la Chimba, vocablo de origen quechua que aludía al barrio "del otro lado del río"112, en este caso, del Mapocho. De hecho, en la Chimba también se encontraba la chacra que Isabel había aportado como dote al matrimonio con Chico, en 1587, y donde también vivía su suegra, india inmigrante quiteña ${ }^{113}$.

El espacio de habitación constituye, pues, un eje adicional que debemos incluir en el análisis de la complejidad social y étnica que hemos estado observando respecto de los indígenas andinos, de su participación en las cofradías y, en sentido más amplio, de su integración en la vida urbana de Santiago.

En esta misma línea podemos identificar a núcleos de personas donde confluye su lugar de residencia -la Chimba- y una cofradía en común -la Candelaria- en el trío formado por el hijo de "cuzca" Lorenzo Ramírez Yáñez y los andinos Pedro Lima y Andrés Bañado Pongo (cinco años separan sus testamentos). Sus oficios, por cierto, eran vinculantes, en la medida en que los dos primeros ejercían como sastres y Bañado era sedero y sombrerero. Por lo demás, uno de los albaceas del testamento de Lima será, justamente, Bañado, a quien denomina como "my compadre" 114 . Sobre Bañado, quien llegó a Chile hacia 1600, es interesante constatar que al momento de testar, en 1624, declaraba estar casado con una india llamada Inés, y que "cuando nos casamos no teníamos nada". Sin embargo, a la fecha había logrado acumular no solo cierto patrimonio material equivalente al de un artesano

111 Testamento de Gaspar (La Chimba, 23 noviembre 1616), ANH.ES, vol. 80, fjs. 190-191v. Juan Chico también había participado como testigo en el testamento que Gaspar dictó tres años antes: Testamento de Gaspar, "indio natural de Jauja" (La Chimba, 3 septiembre 1613), ANH.ES, vol. 81, fjs. $309 \mathrm{v}-310 \mathrm{v}$.

112 "Chimpa: La otra parte o vanda del rio o quebrada acequia, o cosa larga atravesada": Diego González Holguín, Vocabulario de la lengua general de todo el Perú llamada lengua qquichua o del inca [1608], Lima, Universidad Nacional Mayor de San Marcos, 1989, 109-110.

113 Testamento de Isabel de Gálvez (Santiago, 24 agosto 1589), ANH.ES, vol. 6, fjs. 9-10v; Emma de Ramón data este testamento en 1599: "Juan Chico de Peñalosa...”, op. cit., 96-100.

114 Testamento de Pedro Lima (Santiago, 22 octubre 1621), en Retamal, Testamentos..., op. cit., 166-167. 
urbano medianamente acomodado -incluyendo un esclavo negro que le costó cien patacones-, sino también una red de clientes y de vinculaciones con otros artesanos que sin duda avalaban el posicionamiento que hemos visto a nivel de la cofradía agustina ${ }^{115}$.

El sector de la Chimba comenzó a consolidarse a principios de la década de 1560 , justamente con el asentamiento de algunos de los yanaconas andinos que habían venido al servicio de los conquistadores. De hecho, la mayoría de los matrimonios de naturales registrados en las últimas décadas del siglo XVI y que declaran habitar en dicho barrio son, justamente, de indígenas andinos ${ }^{116}$.

Pero, como ya adelantamos, este no fue un espacio exclusivo de esos inmigrantes; también lo fue de aquellos que llegaron en fechas posteriores, provenientes de otras regiones y a través de recorridos individuales, como el citado Bañado Pongo. Fue también el lugar que albergó la diversidad étnica de la ciudad, asentándose allí otros indígenas, de variada procedencia -mapuches del sur, huarpes de Cuyo, juríes del Tucumán-, negros libertos y ladinos, hispanocriollos pobres y la amplia gama de mestizos que nacieron de sus uniones ${ }^{117}$. Por citar un ejemplo, vinculado al ya citado sastre mestizo Juan Chico, vemos que en 1610, en su misma cofradía de Jesús Nazareno, pero aparentemente en otro segmento socioétnico, participaba Gaspar Orense, su muñidor mayor ${ }^{118}$, hijo del descendiente de burgalés Francisco de Orense. Sin embargo, Gaspar era mestizo y en octubre de ese año decidía vender el solar que había heredado de su padre y que se encontraba "de la otra parte del Rio desta ziudad"119.

Otro ejemplo de la complejidad y superposición de posicionamientos religiosoespaciales es el de Pascual de Jesús, maestro sastre indígena que en 1682 era cofrade de Copacabana, pero que al mismo tiempo actuaba como procurador de la cofradía de Nuestra Señora de Renca, establecida en la parroquia del mismo nombre, en un arrabal semiagrícola al norte de Santiago, vecino a la Chimba ${ }^{120}$.

Era en ese sector extraurbano, entonces, en su vida cotidiana y laboral -muchos de los que allí habitaban eran artesanos-, donde se cristalizaron las relaciones

\footnotetext{
115 Testamento de Andrés Bañado Pongo,op. cit., loc. cit.

116 De Ramón, "Bautizos...", op. cit., 232; Tomás Thayer Ojeda, Santiago durante el siglo XVI. Constitución de la propiedad urbana $i$ noticias biográficas de sus primeros pobladores, Santiago, Imprenta Cervantes, 1905, 102.

117 Zúñiga, Espagnols..., op. cit.; Carlos Ruiz Rodríguez, La zona norte de Santiago: población, economía y urbanización, 1540-1833, Tesis de Licenciatura en Historia, Pontificia Universidad Católica de Chile, Santiago, 1986; Mario Góngora, "Vagabundaje y sociedad fronteriza en Chile (siglos XVII a XIX)", Cuadernos del Centro de Estudios Socio-Económicos 2, Santiago, 1966; Hugo Contreras Cruces, “Siendo mozetón o güeñi salió de su tierra a vivir entre los españoles'. Migración y asentamiento mapuche en Chile central durante el siglo XVIII, 1700-1750", Historia indígena 9, Santiago, 2005-2006, 7-32; Ruiz, "Presencia de los mapuche-huilliche...", op. cit.; Valenzuela, "Esclavos mapuches...", op. cit.; San Martín, "Presencias africanas...", op. cit.

118 "Muñidor: El ministro de la cofradía que va avisando a los cofrades que acudan a los entierros": Sebastián de Covarrubias Horozco, Tesoro de la lengua castellana o española [1611], ed. de Ignacio Arellano y Rafael Zafra, Madrid, Iberoamericana, Vervuert, 2006, 1303.

119 Venta de un solar de Gaspar Orense a Manuel González Chaparro (Santiago, 23 octubre 1610), ANH.ES, vol. 40, fjs. 442-443v; Ruiz, "Cofradías...", op. cit., 37, n. 63.

120 Ruiz, "Cofradías...", op . cit., 45.
} 
interétnicas que luego veremos reflejadas en las prácticas desplegadas al interior de la ciudad, particularmente en la composición y organización de las cofradías religiosas.

En efecto, desde temprano la interacción y los contactos entre individuos diferentes congregados en un espacio específico dieron paso a la construcción de redes de intereses, de familia o de amistad entre aquellos actores, configurando procesos de "interdigitación" sociocultural que aparecen como centrales en la configuración de las dinámicas interétnicas ${ }^{121}$. Junto con ello, se desarrollaron estrategias y espacios de integración formal al sistema colonial, tanto en el plano laboral -actividad artesanal, asientos de trabajo, comercio, etc.- como en el plano asociativo -cofradías, "gremios", etc.- y jurídico -utilización de los mecanismos occidentales de herencia y transacción (como los testamentos y contratos notariales), así como el uso de la justicia colonial para zanjar conflictos-, por mencionar algunos de estos escenarios $^{122}$.

Así, las experiencias de la inmigración, de la inserción en un contexto urbano definido por reglas del sistema colonial español, de la integración económica y de la interacción profunda y cotidiana con los "otros" que habitaban la ciudad, permitirán a los indígenas andinos de Santiago un "arraigo" sobre la base de nuevos tejidos comunitarios y corporativos -como las cofradías-, de nuevas identidades sociales y culturales y, eventualmente, de nuevos referentes étnicos, como lo revela el uso del término cuzco por parte de los diversos inmigrantes andinos estudiados ${ }^{123}$.

121 Jacques Poloni Simard, "Redes y mestizajes: propuestas para el análisis de la sociedad colonial", en Guillaume Boccara y Sylvia Galindo (eds.), Lógica mestiza en América, Temuco, Universidad de La Frontera, 2000, 113-138; José Luis Martínez, "Ayllus e identidades interdigitadas. La sociedades de la puna salada", en Boccara y Galindo (eds.), op. cit., 85-112; San Martín, op. cit.

122 Cf. Villalobos, op . cit., IV, 292; José Jouve Martín, Esclavos de la ciudad letrada. Esclavitud, escritura y colonialismo en Lima (1650-1700), Lima, Instituto de Estudios Peruanos, 2005; Jacques Poloni-Simard, "Los indios ante la justicia. El pleito como parte de la consolidación de la sociedad colonial”, en Lavallé (ed.), Máscaras..., op. cit., 177-188.

123 Valenzuela, "Inmigrantes...", op. cit. Con respecto al problema de las categorías étnicas y su uso por parte de las fuentes escritas del período, véase José Luis Martínez, “¿Cómo hablar de indios e identidades en el siglo XVI? Una aproximación a la construcción de los discursos coloniales", Historia indígena 8, Santiago, 2004, 41-55. Para una eventual perspectiva etnogenética de este fenómeno, cf. Stuart Schwartz y Frank Salomon, "New Peoples and New Kinds of People: Adaptation, Readjustment, and Ethnogenesis in South American Indigenous Societies (Colonial Era)", en Frank Salomon y Stuart B. Schwartz (eds.), The Cambridge History of the Native Peoples of the Americas, Cambridge-Nueva York, Cambridge University Press, III:2, 1999, 443-501; Guillaume Boccara, "Mundos nuevos en las fronteras del Nuevo Mundo", Nuevo Mundo-Mundos Nuevos 1, 2001, http://nuevomundo.revues.org/ document426.html; Ana María Lorandi y Mercedes del Río, La etnohistoria. Etnogénesis y transformaciones sociales andinas, Buenos Aires, CEAL, 1992. 